\title{
Review
}

\section{Molecular Chaperones in Parkinson's Disease - Present and Future}

\author{
Darius Ebrahimi-Fakhari ${ }^{\mathrm{a}, \mathrm{b}}$, Lara Wahlster ${ }^{\mathrm{a}, \mathrm{b}}$ and Pamela J. McLean ${ }^{\mathrm{a}, *}$ \\ ${ }^{a}$ MassGeneral Institute for Neurodegenerative Disease, Department of Neurology, Massachusetts General Hospital, \\ Harvard Medical School, Charlestown, MA, USA \\ ${ }^{\mathrm{b}}$ Ruprecht-Karls University Heidelberg, School of Medicine, Heidelberg, Germany
}

\begin{abstract}
Parkinson's disease, like many other neurodegenerative disorders, is characterized by the progressive accumulation of pathogenic protein species and the formation of intracellular inclusion bodies. The cascade by which the small synaptic protein $\alpha$-synuclein misfolds to form distinctive protein aggregates, termed Lewy bodies and Lewy neurites, has been the subject of intensive research for more than a decade. Genetic and pathological studies in Parkinson's disease patients as well as experimental studies in disease models have clearly established altered protein metabolism as a key element in the pathogenesis of Parkinson's disease. Alterations in protein metabolism include misfolding and aggregation, post-translational modification and dysfunctional degradation of cytotoxic protein species.

Protein folding and re-folding are both mediated by a highly conserved network of molecules, called molecular chaperones and co-chaperones. In addition to the regulatory role in protein folding, molecular chaperone function is intimately associated with pathways of protein degradation, such as the ubiquitin-proteasome system and the autophagy-lysosomal pathway, to effectively remove irreversibly misfolded proteins. Because of the central role of molecular chaperones in maintaining protein homeostasis, we herein review our current knowledge on the involvement of molecular chaperones and co-chaperones in Parkinson's disease. We further discuss the capacity of molecular chaperones to prevent or modulate neurodegeneration, an important concept for future neuroprotective strategies and summarize the current progress in preclinical studies in models of Parkinson's disease and other neurodegenerative disorders. Finally we include a discussion on the future potential of using molecular chaperones as a disease modifying therapy.
\end{abstract}

Keywords: Neurodegeneration, Parkinson's disease, alpha-synuclein, Lewy body, molecular chaperone, proteasome, autophagy, lysosome, heat shock protein (Hsp), Hsp90 inhibitor

\section{PART I: THE ROLE OF MOLECULAR CHAPERONES IN PARKINSON'S DISEASE}

\section{INTRODUCTION}

Parkinson's disease (PD) is the second most prevalent neurodegenerative disorder in industrialized countries, currently affecting around $1 \%$ of the popula-

\footnotetext{
*Correspondence to: Pamela J. McLean, MassGeneral Institute for Neurodegenerative Disease, Massachusetts General Hospital, Harvard Medical School, 114 16th Street, Charlestown, MA 02129, USA. Tel.: +1 617726 1263; Fax: +1 617724 1480; E-mail: pmclean@partners.org.
}

tion over the age of 60 years [1]. It is predicted that the incidence of PD will rise dramatically in the coming decades as populations around the globe increasingly age. Clinically, PD is characterized by four cardinal features, namely bradykinesia, rigor, tremor and postural instability, which are often accompanied by other motor- and non-motor symptoms including cognitive impairment [2]. Pathologically, PD is defined by progressive neurodegeneration in defined regions of the brain and the presence of distinct intracellular inclusion bodies, termed Lewy bodies and Lewy neurites [3]. These aggregates are proteinaceous in nature and contain abundant ubiquitinated and phosphorylated 
variants of the small, pre-synaptic protein $\alpha$-synuclein [4]. Lewy bodies and Lewy neurites are not the only defining pathological hallmarks of PD and are also characteristic of Dementia with Lewy bodies (DLB) [4-6]. Moreover $\alpha$-synuclein positive inclusions are found in glia cells in multiple system atrophy [7] and Lewy body pathology has been identified in a variety of other neurodegenerative diseases such as sporadic and familial Alzheimer's disease (AD) [8], Down's syndrome [9] and neurodegeneration with brain iron accumulation type 1 [10]. Besides being a major component of Lewy bodies, the central role of $\alpha$-synuclein in PD has been supported by genetic studies in familial and sporadic forms of the disease. Missense mutations in the gene for $\alpha$-synuclein (A53T, A30P and E46K) [11-13] as well as gene multiplications [14-16] can lead to rare familial cases of PD. In addition, polymorphisms in the $\alpha$-synuclein gene, as identified by several genome-wide association studies, have been confirmed as a major risk factor for sporadic PD [17-19].

A common theme shared by PD and many other neurodegenerative disorders is the abnormal folding or clearance of potentially cytotoxic protein species. The cascade of $\alpha$-synuclein related pathology is believed to progress from the misfolding of $\alpha$-synuclein, to the formation of oligomers, the maturation of protofibrils, and on to heavily insoluble fibrils and finally fullblown aggregates. This process has been recapitulated in vitro, where recombinant wild-type $\alpha$-synuclein has been shown to aggregate and mutations have been found to accelerate the formation of oligomers and protofibrils [20]. Alpha-synuclein has traditionally been described as a natively unfolded monomer of about $14 \mathrm{kDa}$ that acquires an $\alpha$-helical secondary structure upon binding to lipid membranes [21, 22]. A recent study, however, has challenged this notion by demonstrating that $\alpha$-synuclein is present as an $\alpha$-helically folded tetramer when isolated under nondenaturing conditions [23]. Moreover the authors of this study found that cell-derived native $\alpha$-synuclein has a greater lipid-binding capacity compared to the recombinant protein and importantly adopts a helical conformation even in the absence of lipids. Interestingly, the native tetramer also displays a lower propensity to aggregate into fibrils. These compelling results have the potential to significantly impact future research by adding a novel stage to the pathological sequence. Destabilization of the native $\alpha$-helical tetramer conformation may precede $\alpha$-synuclein misfolding and aggregation and thus compounds that stabilize the native tetramers may emerge as novel therapeutic strategies. Looking downstream of this step, a growing body of recent evidence suggests that oligomeric intermediates are indeed the species toxic to neurons [24-27]. Hence, preventing the early steps of oligomerization and aggregation holds the promise to halt the degenerative process associated with protein misfolding and accumulation. Although the exact mechanism by which oligomeric $\alpha$-synuclein contributes to neuronal degeneration is not yet fully understood, one prominent hypothesis suggests that $\alpha$-synuclein oligomers might expose promiscuous hydrophobic domains on the protein, which interact with other proteins or lipid membranes in an aberrant way. Interrupting $\alpha$-synuclein oligomerization is therefore recognized as a potential therapeutic approach. Protein folding and re-folding is mediated by a network of highly conserved molecules termed chaperones and co-chaperones. In order to maintain intracellular protein homeostasis chaperones interact with pathways of protein degradation that regulate the turnover of irreversibly damaged or misfolded proteins. The two major protein degradation pathways for $\alpha$-synuclein in vivo are the ubiquitin-proteasome system (UPS) and the autophagy-lysosomal pathway (ALP) [28]. The latter includes three distinctive subtypes: microautophagy, macroautophagy and chaperone-mediated autophagy. Here, we review the role of molecular chaperones in PD and discuss future therapeutic strategies related to protein folding and degradation.

\section{MOLECULAR CHAPERONES IN THE PATHOGENESIS OF PARKINSON'S DISEASE}

Molecular chaperones or heat shock proteins (HSPs) comprise a heterogeneous group of highly conserved molecules that are critical for maintaining protein homeostasis [29]. Based on their molecular weight they can be classified into different families including HSP40, HSP60, HSP70, HSP90, HSP100 and the small HSPs. While chaperones are molecules that directly mediate the folding of nascent proteins or the renaturation of misfolded proteins, co-chaperones are defined by their assistive role to this process. Important co-chaperones include the BAG-domain containing family (Bag1-6), the TPR-domain containing family (CHIP, Hip, Hop) and the DnaJ-domain containing cochaperone Hsp40. Cells constitutively express specific molecular chaperones to guarantee adequate folding and refolding of client proteins and such homologues of heat shock proteins, known as heat shock cognates (Hsc), are key regulators of basic cell functions. How- 
ever, most chaperones are induced after chemical or physical cell stress, for example as a consequence of hyperthermia, hypoxia, oxidative stress or exposure to toxins [30]. Accumulation of unfolded proteins during cellular stress effectively provokes chaperone expression by a signaling cascade that involves the transcription factor heat shock factor 1 (HSF-1). This regulatory element is part of a feedback loop by which chaperone expression is adjusted to optimize cell survival. In its inactive monomeric state HSF-1 is constitutively present in the cytosol. This resting state is preserved by the association with Hsp90 [31]. Exposure to proteotoxic stress enables HSF-1 to dissociate from Hsp90 to undergo phosphorylation, trimerization, and nuclear translocation. In the nucleus, HSF-1 induces the coordinated expression of Hsp70 and other heat shock proteins via binding to heat shock response elements in the promoter of the respective genes [32]. Once adequate levels of molecular chaperones have reached the cytosol, Hsp90 again stabilizes and inactivates HSF-1, therefore creating a dynamic equilibrium that allows the cell to adjust to endogenous or exogenous stress stimuli $[33,34]$. Chaperones are not only cytoprotective because of their ability to limit protein misfolding and aggregation but also by a wide array of other functions such as stabilization of cytoskeleton elements and anti-apoptotic effects, for example by blocking Apaf1 (Apoptotic protease activating factor 1) signaling [35]. A summary of the many functions of chaperones is provided in Fig. 1. The exact molecular mechanisms of chaperone-mediated protein folding is outside the scope of this review but has been the subject of other recent reviews [29, 36]. With focus on disease mechanisms, molecular chaperone function and malfunction has been implicated in a wide range of diseases [37-39] and their role in neurodegenerative diseases in particular has received considerable attention in recent years [40-43].

\section{Chaperones in Parkinson's disease}

Research exploring the role of molecular chaperones in PD follows seminal studies in other neurodegenerative diseases. Polyglutamine (PolyQ) repeat diseases, such as Huntington's disease (HD) and spinocerebellar ataxia (SCA), have been among the first to be studied in this respect [44-47]. In PD, the first evidence for an involvement of molecular chaperones was provided by pathological studies that identified Hsp90, Hsp70, Hsp60, Hsp40 and Hsp27 as components of Lewy bodies, although to a varying extend [48-51]. Importantly, in one of these initial studies, Auluck et al. [50] demonstrated that Hsp70 co-expression could prevent dopaminergic cell death in a Drosophila melanogaster model of $\alpha$-synuclein toxicity. In the opposite direction, interference with the endogenous chaperone system by introducing a mutation in the ATPase domain of Hsp70 (K71S) exacerbated the pathological phenotype. Despite the dramatic protective effects on cell survival, no change in the number, size or distribution of $\alpha$-synuclein positive perinuclear inclusions was discernible. However, aggregates were found to contain Hsp70 just like Lewy bodies in PD cases. The authors of this seminal report concluded that I) Hsp70 may be a critical part of the neuronal arsenal that mitigates $\alpha$-synuclein toxicity and II) the presence of chaperones in aggregates could result in their cellular depletion, due to sequestration, and thus subsequent loss of chaperone function may lead to degeneration [50] (also see the accompanying editorials [52, 53]). Both hypotheses have been confirmed and extended in subsequent studies (Fig. 1).

\section{Hypothesis I: Molecular chaperones protect neurons against $\alpha$-synuclein induced toxicity}

As detailed above, molecular chaperones are induced in response to cellular stress. Experiments using heat shock induced expression of chaperones demonstrated that induction of Hsp70 can prevent $\alpha$-synuclein induced cell death in a yeast model of PD [54], can mitigate neurotoxicity induced by the mitochondrial toxin rotenone in acute rat brain slices [55] and can significantly ameliorate MPTP (1-methyl-4-phenyl-1,2,3,6-tetrahydropyridine) toxicity in cultured SK-N-SH [56] or PC12 cells [57]. Like heat shock treatment, the insult created by toxins like MPTP, rotenone or lactacystin generated an endogenous although transient heat shock response leading to increased expression of Hsp90, Hsp70 and other chaperones in cultured dopaminergic MES cells [58] and mouse models of PD [49, 59]. Likewise, targeted overexpression of $\alpha$-synuclein in the substantia nigra pars compacta $(\mathrm{SNpc})$ of mice resulted in increased mRNA levels of Hsp70, Hsp40 and Hsp27 as assayed by quantitative PCR (polymerase chain reaction) in dopaminergic cells recovered by laser capture microscopy [60]. Collectively these studies support the general principle that a cellular attempt to counteract proteotoxic stress in disease models involves recruiting molecular chaperones.

Exogenous overexpression of Hsp70 and other chaperones has proven beneficial in various PD models (Fig. 1). In cell culture models of $\alpha$-synuclein aggrega- 


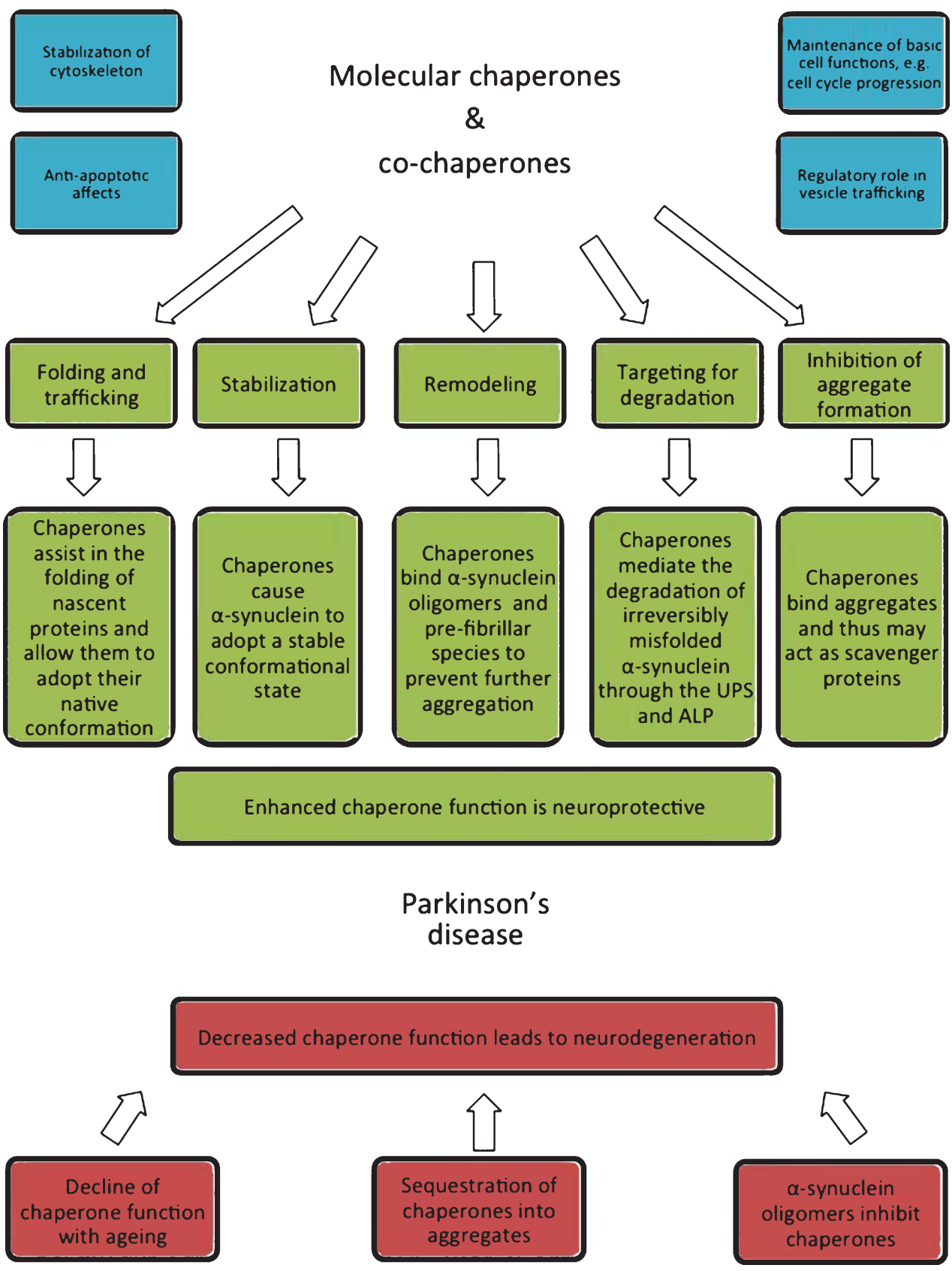

Fig. 1. Synopsis. The role of molecular chaperones in Parkinson's disease can be summarized by two leading hypotheses: I) Molecular chaperones protect neurons against $\alpha$-synuclein induced toxicity and II) Depletion of molecular chaperones exacerbates protein toxicity and neurodegeneration. Molecular chaperones are neuroprotective because of a myriad of actions that mitigate protein misfolding and aggregation. UPS (ubiquitin-proteasome system); ALP (autophagy-lysosomal pathway).

tion and inclusion formation, co-expression of torsinA (a homologue of yeast Hsp104), Hsp40 [48], Hsp27 [61], or Hsp70 [62, 63] led to reduced aggregate formation [48, 61-63] and lowered total and detergentinsoluble fractions of misfolded $\alpha$-synuclein $[62,63]$. Using time-lapse imaging of fluorescently labeled $\alpha$-synuclein, Opazo et al. nicely demonstrated that aggregate formation and toxicity induced by a Cterminally truncated form of $\alpha$-synuclein, could be significantly reduced by co-expressing Hsp70 in living cells [64]. Likewise, Hsp27 was found to be particularly effective in preventing cell death induced 
by mutant $\mathrm{A} 30 \mathrm{P}$ and $\mathrm{A} 53 \mathrm{~T} \alpha$-synuclein in cells [65]. Interestingly, Hsp70 has also been shown to bind $\alpha$ synuclein filaments and mitigate their inhibitory effect on proteasome function, a potentially key pathway for neurodegeneration [66].

In vivo, Klucken et al. confirmed the antiaggregation effect of $\mathrm{Hsp} 70$ overexpression by crossing human $\alpha$-synuclein transgenic mice with transgenic mice overexpressing rat Hsp70 and finding a significant reduction in TritonX-insoluble aggregated $\alpha$-synuclein [63]. By contrast, a recent study found no effect in human A53T mutant $\alpha$-synuclein transgenic mice after crossing with human Hsp70 transgenic mice [67]. This double transgenic mouse line displayed a worse motor phenotype and no change in $\alpha$-synuclein, neither total levels nor aggregation, was discernible, arguing that, at least in this model, frank overexpression of Hsp70 alone does not affect $\alpha$-synuclein pathology or toxicity [67]. The lack of an effect on $\alpha$ synuclein aggregation could be possibly due to a partial dysfunction of overexpressed human Hsp70 in transgenic mice, an explanation that is difficult to prove or disprove in vivo. Supporting this notion, human Hsp70 transgenic mice did not show any change in levels of endogenous $\alpha$-synuclein [67]. Furthermore it seems reasonable to assume that an exclusive overexpression of Hsp70 without the concerted action of other chaperones and co-chaperones is not fully effective in vivo, a lesson that has implications for therapeutics that stably restore or enhance Hsp70.

How do molecular chaperones interfere with $\alpha$ synuclein misfolding and aggregation? A number of studies suggest that molecular chaperones can directly bind $\alpha$-synuclein and inhibit fibrillization (Fig. 1). Zhou et al. [58] found that endogenous Hsp70 is associated with $\alpha$-synuclein aggregates in cultured MES cells after rotenone treatment. Furthermore, the formation of $\alpha$-synuclein aggregates as well as rotenone-mediated mitochondrial inhibition, oxidative stress and cell death were all ameliorated by exogenous overexpression of Hsp70. As for a mechanism, Hsp70 was shown to effectively bind prefibrillar species and in doing so prevent key steps of $\alpha$-synuclein aggregation [68]. These data favor smaller, more soluble species, that are potentially more accessible to mechanisms of protein removal, although no reduction in the net cytotoxic effect of $\alpha$-synuclein aggregation was observed in this in vitro study [68]. Hsc70 was recently found to effectively bind $\alpha$-synuclein fibrils and to sequester $\alpha$-synuclein in an assembly incompetent state but this occurred only in the absence of ATP and in a co-chaperone (Hdj1 and 2) depen- dent manner [69]. When added to a murine cell line (H-END) the Hsc70-coated $\alpha$-synuclein fibrils were significantly less toxic, suggesting a detoxifying effect of chaperone binding to $\alpha$-synuclein aggregates [69]. Looking closer at the molecular interaction of Hsp70 and $\alpha$-synuclein, inhibition of $\alpha$-synuclein fibrillization was found to require a transient and reversible interaction of Hsp70's substrate-binding domain and the core hydrophobic region of soluble $\alpha$-synuclein [70,71]. Using a fluorescence lifetime imaging (FLIM) based assay Hsp70 has been shown to alter $\alpha$ synuclein conformation by inducing it to adopt an open conformational state that discourages the formation of $\alpha$-synuclein- $\alpha$-synuclein intermediates [72]. Thus Hsp70 can reduce $\alpha$-synuclein oligomer formation and toxicity in living cells by specifically preventing or destabilizing $\alpha$-synuclein- $\alpha$-synuclein interactions or by enhancing clearance of oligomeric products [27]. Interestingly, oligomer formation of secreted extracellular $\alpha$-synuclein was found to be dramatically reduced when Hsp70 was co-expressed [73]. This modulatory effect on extracellular $\alpha$-synuclein oligomers was independent of the total level of $\alpha$-synuclein in the extracellular environment and occurred concomitant with an increase in extracellular Hsp70, potentially through simultaneous secretion of $\alpha$-synuclein and the chaperone Hsp70 [73].

Another molecular chaperone that has been shown to affect the process of $\alpha$-synuclein assembly is Hsp90. Hsp90 can bind to $\alpha$-synuclein and abolish its ability to associate with vesicles [74]. Hsp90 can also enhance fibril formation via an intermediate oligomeric pathway, which contrasts findings with Hsp70 and other chaperones and which remains to be evaluated in vivo [74]. The authors of this report suggest that Hsp90, by stabilizing fibrils, may act as a scavenger protein that shifts the equilibrium towards mature fibrils rather than smaller and potentially toxic oligomers [74].

\section{Hypothesis II: Depletion of molecular chaperones exacerbates protein toxicity and neuro- degeneration}

The idea that sequestration of chaperones in protein aggregates could result in a general depletion of chaperones has been explored in post-mortem studies in PD cases and in disease models. Integral to this concept seems the finding that chaperone activity and the resistance to proteotoxic insults declines with aging while proteotoxic stress load increases over the lifetime of a cell. This is particularly true for post-mitotic and high-metabolizing cells like neurons (reviewed in [75, 76]). In PD patients, a polymorphism in the Hsp70-1 
gene was reported that is linked to transcriptional dysregulation and therefore perhaps increases susceptibility to PD [77]. The first post-mortem pathological studies that explored chaperones in PD noted the occurrence of $\alpha \mathrm{B}$-crystallin, a small HSP, or Hsp27 positive neurons in PD patients but not in matched controls $[78,79]$. The distribution of $\alpha \mathrm{B}$-crystallin positive neurons followed a distinct pattern and overlapped with the severity and regional spread of Lewy body pathology, although $\alpha \mathrm{B}$-crystallin was not only restricted to Lewy body baring neurons [79]. As discussed in the previous section, studies have demonstrated the association of several chaperones with PD pathology and promoted the concept that chaperones and other components of protein metabolism might be critical players in PD [48-51]. Following these initial reports, several studies have measured levels of chaperones in different brain regions in PD, DLB and other synucleinopathies and revealed a correlation between levels of chaperones and detergent soluble $\alpha$-synuclein [49, 61, 80-83] suggesting an interaction mainly between chaperones and the bio-available fraction of $\alpha$-synuclein. Expression and protein levels of Hsp90, Hsp70, Hsp40 and Hsp27 were found to be either elevated or unchanged depending on the fraction and tissue used, allowing for no definite conclusions. Interestingly, however, the mitochondrial variant of Hsp70, known as mtHsp70 or mortalin, was found to be decreased in PD [84]. Given the many implications of this protein as an interacting chaperone with DJ-1 and its role in oxidative stress, this could have broader significance for mitochondrial homeostasis and neurodegeneration. Recent findings also suggest that Hsc70, together with other proteins involved in lysosomal targeting and degradation, is significantly reduced in PD cases $[82,85]$. This may indicate impaired chaperone-mediated autophagy as an underlying cause or consequence of PD pathology. Supporting the concept that chaperones are functionally impaired due to sequestration into $\alpha$-synuclein aggregates and mature Lewy bodies, Hinault and colleagues reported that $\alpha$-synuclein oligomers are capable of effectively inhibiting the Hsp70/Hsp40 system by interacting with the J-domain co-chaperones [86].

\section{Chaperones and other key proteins in $P D$}

The relationship of molecular chaperones to other genetically-linked PD proteins has also been explored. Although limited in comparison to the broad investigations of $\alpha$-synuclein, important information can be garnered from these studies. In brief, Hsp70 was found to co-localize with and refold misfolded parkin
(PARK2), allowing it to adopt its native conformation [87]. The Hsp70/Hsp40 complex was also shown to prevent sequestration of parkin into large, stressinduced protein aggregates called aggresomes [88, 89]. Interestingly, a recent study also showed that parkin might interact with mortalin [90] by rescuing the deleterious effects of mortalin knockdown, suggesting that the interaction of parkin and mortalin affects the role of mortalin in mitochondrial homeostasis [90]. DJ-1 (PARK7) expression was shown to lead to increased levels of Hsp70 [91] and wild-type as well as mutant DJ-1 were found to associate with Hsp70, mortalin, and the co-chaperone CHIP (C-terminus of Hsp70 Interacting Protein) following proteasome inhibition [92]. The same study also suggested that translocation of DJ-1 into mitochondria following oxidative stress is carried out in a chaperone dependent manner [92]. In addition, L166P mutant DJ-1 was shown to form a large complex involving interactions with parkin, Hsp70 and CHIP [93]. Although mutations in the small ubiquitin hydrolase, UCH-L1 (PARK5), are not unequivocally a cause of familial PD, it was found to physically interfere with Hsp90, Hsp70, and the lysosomal adapter protein Lamp2a, a known receptor for chaperonemediated autophagy $[94,95]$. The mitochondrial kinase PINK1 (PARK6) appears to be a client protein of Hsp90 and is stabilized, cleaved, distributed, and degraded in an Hsp90 dependent manner [96, 97]. Studies addressing the interaction between $\mathbf{L R R K 2}$ (PARK8), Hsp90 and CHIP are discussed below.

\section{Co-chaperones}

The activity of molecular chaperones is controlled by the dynamic association of various co-chaperones. Co-chaperones can modulate the activity of their chaperones in diverse ways: They can affect the recruitment of client proteins, mediate the binding to other chaperones or regulate their ATPase activity. Cochaperones are also grouped into families. The most important for PD are the BAG-domain containing family (Bag1-6), the DnaJ-domain containing family (HSP40) and the TPR-domain containing family (CHIP, Hip, Hop).

BAG-domain containing chaperones are a heterogeneous family of multidomain proteins. All homologs contain one BAG-domain at their C-terminus except for Bag-5, which contains five. All BAG proteins have been shown to physically interact with Hsp70 but serve different functions [42]. Bag-1 was shown to regulate Hsp70's ATPase domain in a negative fashion [98, 99], potentially by competing with the positive co- 
chaperone of Hsp70, Hip [100]. Bag-2 was found to interact with CHIP, a TPR-domain co-chaperone of Hsp70 that is linked to the UPS through its E3 ubiquitin ligase activity. Bag-3 provides another link to protein degradation pathways because it is associated with both the UPS and autophagy pathways [101, 102]. Bag-5 has been identified as a component of Lewy bodies and has been shown to cooperate with Hsp70 and parkin [88]. It was found to mitigate the refolding capacity of Hsp70 and to inhibit the E3 ubiquitin ligase activity of parkin, therefore providing another important link between the chaperone system, PD and protein degradation [88]. Recently, Bag-5 was found to exist in a complex with both Hsp70 and CHIP [103] in which it inhibits CHIP's E3 ligase activity and thus mitigates CHIP's ability to ubiquitinate $\alpha$-synuclein and to inhibit oligomer formation [103].

TPR-domain containing co-chaperones can bind the C-terminus of Hsp70 or Hsp90 to regulate the association with client proteins and the assembly of the chaperone machinery. The co-chaperone CHIP has particular relevance to PD because of its dual role as an enhancer of Hsp70-mediated protein folding [104] and as an E3 ubiquitin ligase [103, 105, 106]. CHIP can therefore act as a co-chaperone that links the chaperone network to protein degradation pathways and the ubiquitin-proteasome system in particular [107, 108]. CHIP was also found to associate with parkin and to possibly act as an E4 ubiquitin ligase-like protein that enhances the E3 ligase activity of parkin [109]. CHIP is a component of Lewy bodies in DLB [110] and tau aggregates in AD [111]. Perhaps most interesting, CHIP ubiquitinates and associates with $\alpha$-synuclein and can prevent the formation of toxic $\alpha$-synuclein oligomers by facilitating removal via both the proteasome and lysosomal pathways [103, 110, 112]. In two recent studies, CHIP was found to associate with LRRK2 and Hsp90, forming a complex that regulates LRRK2-induced toxicity through modulation of LRRK2 stability via the action of CHIP's ligase activity $[113,114]$. In this complex Hsp90 was found to interact with LRRK2 and to mitigate CHIP-mediated degradation of LRRK2 through the proteasome [113-116]. Hip, another TPR-domain containing co-chaperone of Hsp70, was recently identified as a possible player in PD by a transcriptome wide screen that revealed significantly decreased levels of Hip mRNA in PD patients compared to controls [117]. In addition, it recently became evident that Hip can prevent the co-aggregation of Hsp70 and $\alpha$-synuclein, therefore recovering levels of biologically active Hsp70 [118]. Hence, Hip can be viewed as an interesting target for therapeutic strategies that aim to prevent chaperone sequestration in $\alpha$-synuclein aggregates.

Taken together, the studies reviewed above strongly implicate a role for molecular chaperones in the pathogenesis of PD (Fig. 1). Evidence is derived from pathological and genetic studies in PD patients and pathophysiological studies in a variety of disease models. The data discussed suggest that chaperones and the Hsp70 system in particular can suppress toxicity associated with $\alpha$-synuclein or the other proteins implicated in PD. This growing body of investigations sets the stage for approaches that target molecular chaperones as a disease modifying therapy in PD, as reviewed in the following section.

\section{PART II: MOLECULAR CHAPERONES AS A NOVEL THERAPEUTIC TARGET IN PARKINSON'S DISEASE}

\section{MOLECULAR CHAPERONES AS A THERAPEUTIC TARGET}

Treatment of neurodegenerative disorders is a challenge to clinicians because of the slow progressive nature of the disease, the profound neurodegeneration prior to the onset of clinical symptoms and the lack of early diagnostic biomarkers. To date, therapeutics for $\mathrm{PD}$ are aimed at increasing cerebral dopamine levels or stimulating central dopamine receptors, respectively. Levodopa, in combination with a peripheral dopa-decarboxylase inhibitor, remains the mainstay for initial therapy in most cases. Surgical measures include deep-brain-stimulation, which has been recognized as an effective therapy for selected cases. While these treatment options substantially improve quality of life and functional capacity for a variable period of time, no current treatment halts or reverses neuronal degeneration in PD $[119,120]$. As the disease progresses, first and second-line options for symptomatic treatment of motor and non-motor manifestations, including cognitive impairment, eventually fail, leaving patients severely disabled. The cause of death in many patients with PD remains obscure but pneumonia is the most common explanation given the problems of disease management in the terminal phase of the illness. Because current clinical trials have been unable to establish neuroprotective therapies for clinical use, significant effort now focuses on the identification of novel disease modifying agents [119, 121]. Targeting well-characterized molecular pathways in the pathogenesis of neurodegenerative 


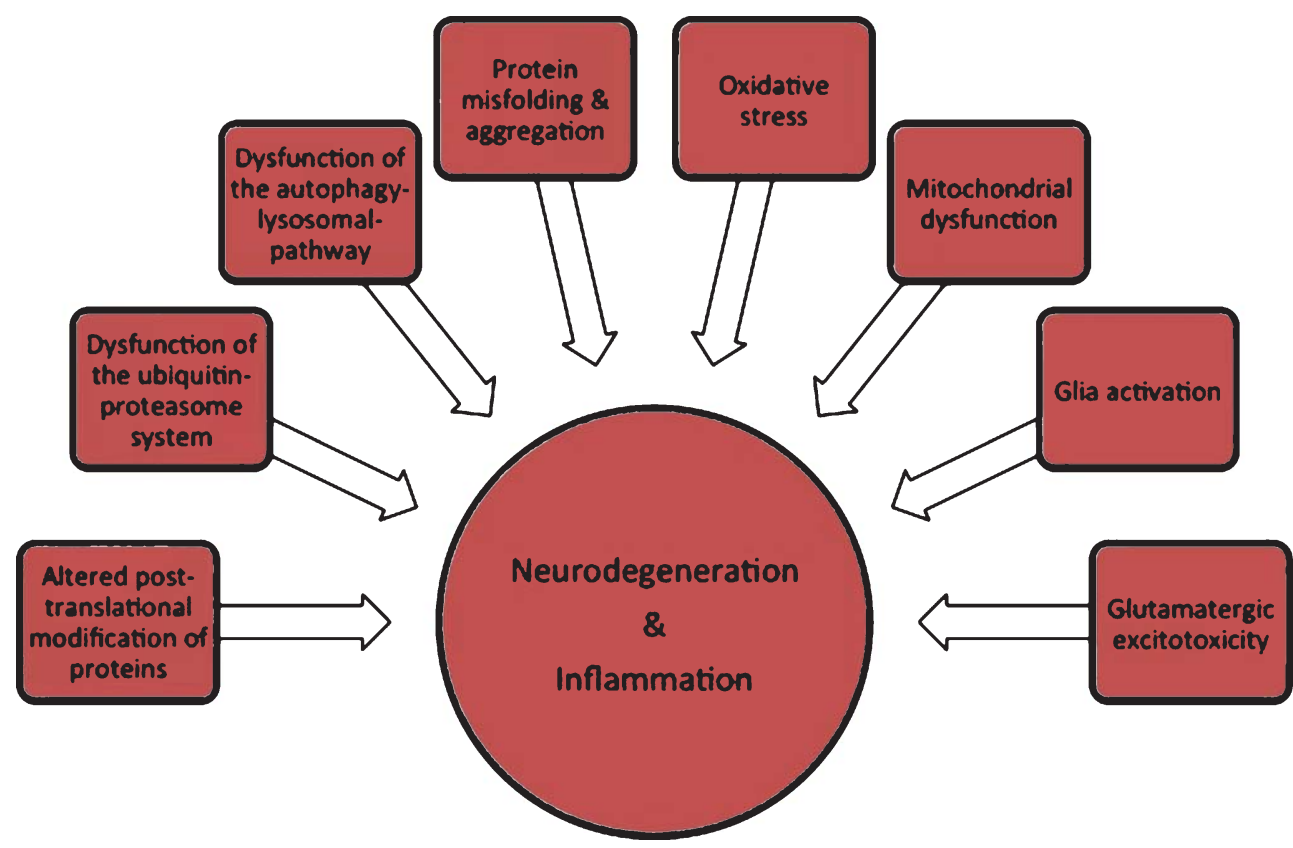

Fig. 2. Synopsis of the pathological cascades proposed to be involved in Parkinson's disease. Mechanisms at play include altered protein metabolism and mitochondrial function as well as cellular stress induced by reactive-oxygen species or glutamatergic excitotoxicity. All pathways are interrelated and converge into the final steps of neurodegeneration and inflammation.

disorders will lead to rational drug design and testing of novel disease modifying agents. Emerging pathways for potential therapeutic targets include mechanisms of oxidative stress, mitochondrial dysfunction, glutamate excitotoxicity, apoptosis and protein metabolism (Fig. 2). Targets in protein metabolism pathways include misfolding and aggregation, post-translational modifications, and protein degradation pathways such as the UPS and the ALP. Pathologically misfolded proteins may cause cellular dysregulation and damage by a variety of interrelated mechanisms, including aggregation and misfolding of other proteins, inhibition of chaperones by direct interaction and sequestration into aggregates, impairment of protein degradation pathways, membrane destabilization and synaptic dysfunction with these pathological events all converging at the same endpoint - cell death and inflammation.

As discussed in the previous section, protein folding and refolding involves the orchestrated action of a network of interacting molecules. The highly conserved machinery of molecular chaperones acts in conjunction with degradation pathways to effectively eliminate misfolded or damaged proteins. It is noteworthy that in the context of neurodegeneration, these mechanisms of protein quality control significantly change in the aging brain, eventually paving the way for protein conformational disorders associated with aging [75, 76]. Although the molecular cascade leading to pathological accumulation and aggregation of $\alpha$-synuclein and other proteins in PD is yet not fully understood, protein homeostasis appears to be a key element. Therefore molecular chaperones hold the promise to alter early pathological changes in proteinopathies such as PD [40, 42]. It is widely recognized that the Hsp70 chaperone system is an important cellular defense element that can halt, prevent and eventually even reverse protein misfolding and neurodegeneration.

A growing number of preclinical studies have investigated pharmacological and gene therapy strategies to upregulate chaperone function with promising results. While a few recent studies have tested brain permeable small molecule enhancers of chaperone function in animal models of PD, a lot of the ideas for our current concepts stem from studies in other neurodegenerative disorders and various forms of cancer. Based on their mechanism of action many of the agents tested in other diseases may be suitable for studies in PD. 


\section{PHARMACOLOGICAL UPREGULATION OF MOLECULAR CHAPERONES}

Pharmacological agents targeting molecular chaperones have mainly focused on the Hsp70 system and can be classified in three groups: 1) Hsp90 inhibitors, 2) modulators of HSF-1 and 3) compounds with direct chaperone activity (Table 1$)$.

\section{Hsp90 inhibitors}

Hsp90 inhibitors increase the activity of the transcription factor HSF-1 and thus lead to increased expression of stress-induced proteins such as Hsp70 $[31,122]$. As detailed above, the interplay between Hsp90 and HSF-1 can be regarded as a molecular switch that can activate a cytoprotective stress-res- ponse that will counteract the pathogenic aggregation of proteins [123]. A wealth of information about Hsp90 inhibitors has been generated in cancer studies (reviewed in [37, 39, 124, 125]). In cancer cells, Hsp90 protects a range of mutated or overexpressed oncoproteins from misfolding and degradation. Hence, Hsp90 can be regarded as a crucial line of support for cancer cell survival. This knowledge has led to considerable progress in the development of small molecule inhibitors of Hsp90 with more than 60 completed or ongoing clinical trials for various forms of cancer. The first inhibitor to enter clinical trials was 17-AAG (tanespimycin) in 1999 and since then numerous other inhibitors have undergone clinical testing [124, 125]. Parallels with the cancer studies can be drawn to neurodegenerative disorders where the detrimental consequences of an inefficient degradation of pathogenic proteins are equally dramatic.

Table 1

Molecular chaperones as a therapeutic target

\begin{tabular}{|c|c|c|}
\hline \multicolumn{3}{|c|}{ A) Pharmacologic upregulation of molecular chaperones } \\
\hline Compound & Target & Investigated for \\
\hline Geldanamycin & Hsp90 inhibitor & $\begin{array}{l}\text { PD [54, 127-129, 133-135] } \\
\text { AD [111] } \\
\text { ALS [139, 140] } \\
\text { PolyQ disease [136-138, 210] }\end{array}$ \\
\hline 17-AAG & Hsp90 inhibitor & $\begin{array}{l}\text { PD }[73,113,114,144,145] \\
\text { ALS [211] } \\
\text { PolyQ disease }[146,147,210,211]\end{array}$ \\
\hline 17-DMAG & Hsp90 inhibitor & PolyQ disease [212] \\
\hline SNX-0723 and others & Hsp90 inhibitor & $\mathrm{PD}[144]$ \\
\hline Arimoclomol & HSF-1 enhancer & ALS $[150-152]$ \\
\hline HSF1A & HSF-1 enhancer & PolyQ disease [159] \\
\hline Celastrol & Hsp70 induction & $\begin{array}{l}\text { PD }[162,163] \\
\text { AD }[213] \\
\text { ALS }[164] \\
\text { PolyQ disease }[165,166]\end{array}$ \\
\hline Geranylgeranylacetone (GGA) & Hsp70 induction & PolyQ disease [171] \\
\hline Valproic acid & Hsp70 induction & $\begin{array}{l}\text { PD [176, 177] } \\
\text { AD [214] } \\
\text { ALS [215] } \\
\text { PolyQ disease [216] }\end{array}$ \\
\hline \multirow[t]{4}{*}{ Trehalose } & \multirow[t]{4}{*}{$\begin{array}{l}\text { Direct chaperone function and mTOR independent } \\
\text { autophagy induction }\end{array}$} & $\mathrm{PD}[184,185]$ \\
\hline & & $\mathrm{AD}[185,217,218]$ \\
\hline & & ALS [219] \\
\hline & & PolyQ disease $[183,184,220]$ \\
\hline \multicolumn{3}{|l|}{ B) Viral-mediated upregulation of chaperone function } \\
\hline \multirow[t]{2}{*}{ AAV-Hsp70 } & \multicolumn{2}{|l|}{ MPTP mouse model of PD [191] } \\
\hline & \multicolumn{2}{|l|}{ AAV-CDCrel-1 rat model of PD [193] } \\
\hline \multirow{3}{*}{$\begin{array}{l}\text { AAV-H-BH (constitutively active form of HSF-1) } \\
\text { LV-Hsp104 } \\
\text { AAV-BAG5 (DARA) }\end{array}$} & \multicolumn{2}{|c|}{ AAV-CDCrel-1 rat model of PD [193] } \\
\hline & \multicolumn{2}{|c|}{ LV-(h)A30P $\alpha$-synuclein rat model of PD [194] } \\
\hline & \multicolumn{2}{|c|}{ MPTP mouse model of PD [88] } \\
\hline \multicolumn{3}{|c|}{ C) Cell-penetrating peptide technology-mediated upregulation of chaperone function } \\
\hline TAT-Hsp70 & \multicolumn{2}{|l|}{ MPTP in cell culture [198] } \\
\hline
\end{tabular}




\section{Geldanamycin and analogues}

Geldanamycin (GA) is a naturally occurring Hsp90 inhibitor and the lead compound for a group of agents termed ansamycin antibiotics [126]. This class of inhibitors acts by replacing ATP in the ATP binding pocket in the $\mathrm{N}$-terminal domain of the Hsp90 chaperone [126]. GA has been well characterized in different PD models. Several studies in cultured cells have demonstrated that GA can reduce $\alpha$-synuclein oligomerization, aggregation and increase $\alpha$-synuclein clearance [127-129]. Interestingly, inhibition of Hsp90 with GA also leads to reduced re-secretion of extracellularly applied $\alpha$-synuclein via exocytosis and attenuates extracellular $\alpha$-synuclein toxicity induced by the neurotoxins rotenone and MPTP [129]. Similarly, upregulation of Hsp70 in $\alpha$-synuclein transfected cells by $\mathrm{Hsp} 90$ inhibition resulted in a reduction in secreted, extracellular $\alpha$-synuclein oligomers and attenuated their toxic effects [73]. Secretion of $\alpha$-synuclein is essential to the proposed mechanism of prion-like cellular transmission and spreading of $\alpha$-synuclein pathology, a very exciting new avenue in PD research [130]. The influence of molecular chaperone function on secretion and uptake of $\alpha$-synuclein might therefore be of great interest for future studies. A second noteworthy discovery is that GA regulates AMPA (2-amino-3(3-hydroxy-5-methyl-4-isoxazolyl)propionic acid) receptor trafficking and therefore may be able to reduce glutamatergic excitoxicity $[131,132]$. With regards to PD pathogenesis, GA was shown to prevent dopaminergic cell death and $\alpha$-synuclein-induced pathology in cell culture [127], Drosophila melanogaster [50, $133,134]$ and the MPTP mouse model of PD [135]. Besides PD, GA has also shown beneficial effects in models of several other important neurodegenerative disorders, including models of HD [136-138], AD [111] and amyotrophic lateral sclerosis (ALS) [139, 140]. Despite these very encouraging findings, the use of GA has been limited by a variety of reasons but mainly because of its poor aqueous solubility, poor blood-brain barrier permeability and significant liver toxicity [141]. Analogues of GA have been able to partly overcome these limitations and also show higher affinity for Hsp90 [142]. 17-AAG (17-allylamino17-demethoxygeldanamycin, or tanespimycin) and 17-DMAG (17-dimethylaminoethylamino-17demethoxygeldanamycin, or alvespimycin) are potent Hsp90 inhibitors with an improved side-effect profile [143]. 17-AAG ameliorates $\alpha$-synuclein toxicity, decreases intracellular $\alpha$-synuclein levels in cultured cells [144] and prevents extracellular $\alpha$-synuclein oligomerization [73]. Recent studies have shown that 17-AAG influences the interaction between LRKK2, CHIP and Hsp90 and can reduce LRRK2 toxicity by promoting degradation through the proteasome $[113,114]$. Importantly, 17-AAG was also found to effectively induce macroautophagy and hence facilitate clearance of $\alpha$-synuclein [145]. Like GA, treatment with 17-AAG has proven beneficial in several models of neurodegeneration, e.g., 17-AAG suppressed polyglutamine-induced neurodegeneration in an HSF-1 dependent manner in Drosophila melanogaster models of HD and SCA [146]. An elegant study by Waza et al. [147] demonstrated the therapeutic potential of 17-AAG in a mouse model of spinal bulbar muscular atrophy (SBMA). In this disease, Hsp90 is required to stabilize mutant androgen receptors. By blocking Hsp90, 17-AAG treatment destabilizes the pathogenic receptor and Hsp70 upregulation accelerates its degradation, leading to a significantly ameliorated phenotype in this model. As well as these promising findings for neurodegeneration, 17-AAG is currently being evaluated in several phase II/III trials for various forms of cancer [39, 125]. Although it has been shown to be safe for humans, poor blood brain barrier permeability remains a limiting factor for its clinical use for neurodegenerative disorders. 17-DMAG is an advanced formulation of 17-AAG with improved aqueous solubility but unfortunately was found to be associated with unacceptable toxicity in cancer trails [125]. Taken together the clinical utility of GA, 17-AAG and 17-DMAG is questionable, despite very encouraging results from studies in various disease models.

\section{Novel Hsp90 inhibitors: SNX compounds}

An interesting novel group of synthetic small molecule inhibitors of Hsp90 are derived from a compound termed SNX-2112 (4-[6,6-dimethyl-4-oxo-3(trifluoromethyl)-4,5,6,7-tetrahydro-1H-indazol-1-yl] -2-[(trans-4-hydroxycyclohexyl)amino]benzamide). Developed for their potent Hsp90 inhibition and excellent antitumor activity [148, 149], novel derivatives of SNX-2112 (see below) have important advantages: they selectively inhibit Hsp90, are orally available and display excellent blood brain barrier permeability. In a recent study, a panel of SNX compounds, selected for their chemical properties to favor brain penetration, was assessed for effects on $\alpha$-synuclein oligomerization and toxicity in cell culture models [144]. In the study by Putcha et al., a 
significant reduction of $\alpha$-synuclein oligomerization was achieved in transfected cells [144]. Additionally, a subset of SNX compounds effectively reduced both high-molecular weight and monomeric species of $\alpha$-synuclein. These findings suggest that SNX compounds promote refolding and degradation of $\alpha$-synuclein through the efficient induction of Hsp70 by Hsp90 inhibition. A lead compound, SNX-0723, was identified based on its strong preventive effect on $\alpha$-synuclein oligomerization and in vivo pharmacokinetic and pharmacodynamic studies demonstrated robust brain absorption and excellent bioavailability, making this compound a promising candidate for further evaluation.

\section{Modulators of HSF-1}

Modulation of HSF-1 activity has received considerable attention as a therapeutic strategy because, by promoting the expression of Hsp70 and other chaperones, modulators of HSF-1 tackle intracellular chaperone function at the transcriptional level. Recruitment of Hsp70 and other chaperones to actively unfold and disassemble stress-induced protein aggregates can prevent the accumulation of toxic protein species.

\section{Arimoclomol}

One modulator of HSF-1, Arimoclomol, has received considerable attention as a potential ALS therapy [150-155] and thus may be a good candidate for study in PD. Arimoclomol, a derivate of bimoclomol $[156,157]$, is an orally administered drug that acts through co-induction of HSF-1 under stress conditions [158]. After providing evidence for improved motor function, motor neuron survival and increased life span in SOD1 mutant mice [151], Arimoclomol is now in clinical testing for ALS [152]. It was found to have adequate tolerability and safety in a phase I/IIa clinical trial [152]. Now in a phase II/III clinical trial, results are awaited eagerly. It is important to understand that Arimoclomol co-induces HSP expression by prolonging the binding of HSF-1 to the heat shock response element found in heat shock gene promoters $[151,158]$. Therefore it acts only under conditions of cellular stress and ongoing heat shock response [151], an important feature that may convey selectivity for stressed neurons, e.g., dopaminergic cells in PD.

\section{HSF 1A}

Given the importance of HSF-1 as the master regulator of chaperone gene transcription and the lim- itations of global Hsp90 inhibition, small molecules that directly modulate this transcription factor are of great interest. A recently published study [159], used a sophisticated high-throughput screen in yeast to identify a novel activator of HSF-1, coined HSF1A. This novel small molecule increases chaperone protein expression by promoting key steps of HSF-1 activation without binding or affecting Hsp90. HSF1A was found to enhance HSF-1 trimerization, translocation into the nucleus and activation through phosphorylation. HSF1A-mediated Hsp70 induction reduced the de-novo formation of protein aggregates and ameliorated polyglutamine-induced cytotoxicity in both a cell-culture and Drosophila melanogaster model of HD [159].

\section{Celastrol}

Celastrol is an effective Hsp70 inducer, although its mechanisms of action are pleiotropic and include anti-inflammatory and anti-oxidant properties [160]. Celastrol not only induces the hyperphosphorylation of HSF-1 and triggers its binding to chaperone gene promoters, it also regulates Hsp90's binding to cochaperones [161]. Important to PD, celastrol treatment significantly attenuated MPTP-induced cell death and partly restored striatal dopamine levels in the MPTP mouse model [162]. In addition, it was also neuroprotective in a Drosophila melanogaster model of PD [163]. In the mutant SOD1 mouse model of ALS, orally administered celastrol resulted in delayed disease onset, improved motor function, and attenuated cell loss in the lumbar spinal column [164]. Likewise celastrol prevented polyglutamine aggregation and toxicity in transfected cells $[165,166]$.

\section{Geranylgeranylacetone}

Another interesting compound is geranylgeranylacetone (GGA). Originally developed as an antiulcer drug, GGA has been shown to be neuroprotective in animal models of transient cerebral ischemia [167-169] and cerebral hemorrhage [170] through effective induction of $\mathrm{Hsp} 70$ potentially via protein kinase $\mathrm{C}$ mediated phosphorylation of HSF-1 [167-169]. Furthermore, GGA suppressed polyglutamine-induced toxicity in cell culture and a mouse models of SBMA [171].

\section{Valproic acid \\ Valproic acid is a classic anticonvulsive drug used in treating epilepsy and as a mood-stabilizing agent prescribed for bipolar disorder. Laboratory studies have identified valproic acid as a histone deacety-}


lase (HDAC) inhibitor and inducer of Hsp70 [172]. It is cytoprotective under conditions of oxidative stress [173-175] and thus relevant to PD, against rotenone toxicity in cultured cells [176] and rats [177].

\section{Statins}

Other widely used drugs that potentially exert protective effects through modulation of molecular chaperone activity are statins. Statins or HMG-CoA (3-hydroxy-3-methyl-glutaryl coenzyme A) reductase inhibitors are important and frequently prescribed therapeutics for lowering cholesterol levels as a preventive measure for cardiovascular disease. Besides the known effects on cholesterol synthesis, statins may have pleiotropic actions including immunomodulatory, anti-oxidative and anti-apoptotic effects [178]. The impact of statin therapy on PD has been explored in laboratory and epidemiological studies but to date it remains an open question whether long-term treatment with statins will influence the risk and progression of PD in a favorable or unfavorable way [178]. With regards to neuroprotection, it is noteworthy that statins have been shown to target molecular chaperones, e.g., by effecting the phosphorylation of Hsp90 [179] or by stimulating the expression of Hsp27 [180, 181], although the relevance of these findings to PD pathology still has to be evaluated in detail.

\section{Compounds with direct chaperone activity}

Another attempt to promote protein homeostasis under cellular stress conditions involves the addition of so-called chemical chaperones. These molecules minimize unproductive protein-protein interaction and stabilize partly folded intermediates during refolding or aggregation. Chemical chaperones can act synergistically with molecular chaperones and additionally may interact with protein degradation pathways.

\section{Trehalose}

Direct chaperone activity has been ascribed to trehalose, a stable disaccharide with unique physicochemical properties [182]. Trehalose acts as a chemical chaperone through direct protein-trehalose interaction and protects cells against various stress conditions. For example, trehalose binds to PolyQ expanded mutant huntingtin, which leads to reduced disease pathology and toxicity in vitro and in vivo due to stabilization of the partly unfolded mutant protein [183]. In multiple cell lines it was demonstrated that trehalose can induce autophagy and thus facilitate clearance of aggregateprone proteins including mutant $\alpha$-synuclein [184,
185]. In addition to not being toxic to cells, trehalose was found to have anti-apoptotic properties through enhanced removal of pro-apoptotic proteins via autophagy [184]. This myriad of protective actions, covering both direct chaperone function and enhancement of degradation mechanisms, together with its lack of toxicity, give trehalose qualities that might be useful for studies in many neurodegenerative disorders including PD.

\section{VIRAL VECTOR-MEDIATED UPREGULATION OF MOLECULAR CHAPERONES}

Gene therapy approaches promise important advantages over pharmacological strategies with small-molecules. With the goal being a stable, targeted restoration of cellular deficits and the prevention of disease progression, gene therapy has, in theory, the potential to ameliorate or even cure PD. Besides the transplantation of fetal grafts, viral vector-mediated expression of trophic factors or transmitter enzymes has emerged as a promising new avenue for curative approaches (reviewed in [186, 187]). After a series of proof-of principle phase I studies for viral vectorbased strategies, randomized controlled double-blind clinical trials are underway [188, 189]. Based on their properties, such as stable gene expression, specificity and a favorable safety profile, only adeno-associated virus (AAV) and lentiviral vectors are currently in clinical testing [190]. Viral vector-based strategies may provide novel ways to upregulate the expression and activity of neuroprotective chaperone systems in vulnerable neuron populations at risk. Preclinical studies in animal models of PD have provided evidence for the potential of viral-mediated Hsp70 expression (Table 1). In the MPTP mouse model, Hsp70 gene transfer to striatal dopaminergic neurons by a recombinant AAV vector protected against MPTPinduced dopaminergic cell death and the associated decline in striatal dopamine levels [191]. Another study using a rat model of $\mathrm{PD}$, based on AAV-mediated overexpression of CDCrel-1, a parkin substrate toxic to dopaminergic cells, showed that AAV-mediated overexpression of Hsp70 or mutant H-BH [192], a constitutively active form of HSF-1, can prevent dopaminergic neurodegeneration [193]. Although only a moderate improvement (approximately 20\%) in survival of dopaminergic neurons could be achieved in this model, the study supports viral-mediated upregulation of Hsp70 as a novel target for neuroprotection. In 
contrast to the encouraging data for Hsp70 overexpression or HSF-1 enhancement, targeted overexpression of Hsp40 did not prevent but exacerbated neurodegeneration in the same study, a controversy that remains to be explained [193].

Recombinant viral vectors have also been used to investigate neuroprotection by exogenous expression of Hsp70 interacting proteins. Co-injection of Hsp104 and $\mathrm{A} 30 \mathrm{P}$ mutated $\alpha$-synuclein into the substantia nigra of rats using lentiviral vectors reduced the formation of phosphorylated $\alpha$-synuclein inclusions and prevented nigrostriatal dopaminergic neurodegeneration induced by mutant A30P $\alpha$-synuclein [194].

The co-chaperone BAG5 interacts with Hsp70 and serves as a negative regulator for $\mathrm{Hsp70-}$ mediated refolding of client proteins [88]. A mutant form of BAG5, termed BAG5 (DARA), however, binds to wild-type BAG5 and therefore compromises BAG5-HSP70 interaction [88, 103]. AAV-mediated expression of BAG5 (DARA) in the SNpc of MPTPtreated mice resulted in an increased survival of dopaminergic neurons while targeted expression of BAG5 enhanced degeneration [88].

\section{CELL-PENETRATING PEPTIDE TECHNOLOGY-MEDIATED UPREGULATION OF MOLECULAR CHAPERONES}

Apart from viral-mediated expression, cellpenetrating peptides (CCP) have emerged as an alternative strategy to deliver or enhance chaperones in neurons [195, 196]. CCPs are small, basic protein domains that can deliver compounds across cell membranes and the blood-brain-barrier. The most commonly used CCP is the basic domain of TAT (trans-activator of transcription) derived from the human immunodeficiency virus (HIV) [195, 196]. Delivery and cell-penetration of Hsp70 can be enhanced by fusion to TAT. Administration of TATHsp70 increases levels of Hsp70 in cultured primary neurons and efficiently protects against peroxinitrite and glutamate-induced cell stress [197]. In models of PD, TAT-Hsp70 protected primary neurons and cultured mesencephalic neurons against the insult of MPTP [198]. When administered systemically in mice through intraperitoneal injection, penetration through the blood-brain-barrier and transduction of dopaminergic neurons of the SNpc was observed [198]. Again, TAT-Hsp70 protected against MPTP toxicity, leading to increased survival and integrity of dopaminergic neurons in this model. Preliminary studies also suggest that CCP-mediated delivery of Hsp40 or HSF-1 can increase Hsp70 expression and function, thus potentially exerting similar protective effects [199, 200]. Although clearly advantageous as described above, the clinical usefulness of CCPmediated delivery of molecular chaperones or $\mathrm{CCP}$ technology in general remains to be determined in future studies.

\section{CONCLUDING REMARKS AND FUTURE CHALLENGES}

A number of exciting therapeutic interventions targeting molecular chaperone function are under development for use in PD. Promising candidates include small molecule inhibitors of Hsp90 and gene therapy strategies to upregulate Hsp70. Important lessons can be learned from studies in other neurodegenerative conditions, where compounds have already entered clinical trials. Parallels can also be drawn to studies in cancer where drug development and evaluation has pushed forward at a miraculous pace. Despite encouraging results in disease models and the existence of exciting new compounds waiting to be tested for PD, the same limitations that apply to all neuroprotective therapies on trial will challenge testing of chaperone-based therapeutics.

Neuroprotection has been defined as an intervention "that produces enduring benefits by favorably influencing the underlying etiology or pathogenesis and thereby forestalling onset of illness or clinical decline" [201]. The challenges for testing neuroprotective therapies today include, but are not limited to, the following issues:

1) Evaluation of beneficial effects in currently available animal models is limited because no model convincingly recapitulates all features of PD pathology [202]. Toxin-based models are adequate to study effects of dopamine-replacement therapies but may not appropriately mimic the slow and progressive nature of neurodegeneration in PD patients. Genetic models also have their caveats [203-205]. The level of nigrastriatal pathology is relatively modest in most models and a strong disease phenotype is clearly missing. An approach to combine genetic models with the application of neurotoxins may provide a novel concept, more suitable for preclinical testing of neuroprotective strategies [206]. 
2) Clinical trial design has also been a challenge for testing neuroprotective effects in PD patients. The range of difficulties faced in current trials is outside the scope of this discussion but has been the subject of numerous excellent reviews and editorials [119, 120]. Importantly, population selection, timing of the intervention, appropriate endpoints, and readouts such as novel biomarkers are areas of uncertainty and call for improvement.

3) Clinical parkinsonism is heterogeneous in terms of underlying pathology with regards to cause, severity and progression. Enhancement of chaperone function holds the promise to prevent protein misfolding, accumulation and aggregation and hence cell death. It remains a conceptual question, however, if a single agent targeted at a single pathway, among numerous other established disease pathways, will have an enduring neuroprotective effect. This challenge obviously applies to therapeutics that aim at improving molecular chaperone function. The idea of using a combination of agents for the same pathway in conjunction with agents that target different pathways seems only natural to overcome this problem. In this respect, much can be learned from drug development in other diseases such as cancer or atherosclerosis. As an example, a combination of chaperone inducing agents with agents that facilitate protein clearance via the UPS [207] or ALP [208, 209] seems to be a potential testable approach.

4) Biomarkers are tools that assist in finding the right diagnosis, tracking disease progression and that help in identifying new therapeutic targets. Despite significant efforts, reliable biomarkers for the pre-clinical phase of PD have been notoriously difficult to establish. Neuroprotective therapies, aimed at preventing neurodegeneration, however, will have their greatest impact during the pre-symptomatic phase of the disease, before significant pathology has accumulated. The translation of novel techniques in genomics, proteomics and metabolomics into reliable, sensitive and specific biomarkers will therefore be a crucial step for testing of disease modifying agents.

In summary, targeting molecular chaperones as a therapeutic strategy in PD is a viable approach to prevent or modify disease progression. Small molecules and gene therapy strategies have already shown very encouraging results in proof-of-concept pre-clinical studies. With the limitations discussed above, the development of novel compounds applicable to clinical testing is anticipated and future studies will determine the best approach for using molecular chaperones to tackle protein toxicity in PD.

Glossary: AAV (adeno-associated virus); AD (Alzheimer's disease); ALP (autophagy-lysosomal pathway); ALS (amyotrophic lateral sclerosis); CCP (cell-penetrating peptides); DLB (Dementia with Lewy bodies); GA (Geldanamycin); GGA (geranylgeranylacetone); HD (Huntington's disease); Hsp (heat shock protein); MPTP (1-methyl-4-phenyl-1,2,3,6tetrahydropyridine); PD (Parkinson's disease); SCA (spinocerebellar ataxia); SnPC (substantia nigra pars compacta); SBMA (spinal bulbar muscular atrophy); TAT (trans-activator of transcription); UPS (ubiquitin-proteasome system); LV (lentivirus); PolyQ (polyglutamine).

\section{CONFLICT OF INTEREST}

None.

\section{ACKNOWLEDGMENTS}

We thank the peer reviewers for their valuable and thoughtful comments, which have led to a substantial improvement of the manuscript.

This work was supported by grants from the National Institute of Health (P.J.M.), the German National Academic Foundation (Studienstiftung des deutschen Volkes) (D.E.-F. \& L.W.), the Hamburg Foundation for International Research and Studies (D.E.-F.) and the Parkinson's Disease Foundation (D.E.-F.).

\section{REFERENCES}

[1] de Lau LM, \& Breteler MM (2006) Epidemiology of Parkinson's disease. Lancet Neurol, 5, 525-535.

[2] Lees AJ, Hardy J, \& Revesz T (2009) Parkinson's disease. Lancet, 373, 2055-2066.

[3] Shults CW (2006) Lewy bodies. Proc Natl Acad Sci U S A, 103, 1661-1668.

[4] Spillantini MG, Crowther RA, Jakes R, Hasegawa M, \& Goedert M (1998) alpha-Synuclein in filamentous inclusions of Lewy bodies from Parkinson's disease and dementia with lewy bodies. Proc Natl Acad Sci U S A, 95, 6469-6473.

[5] Hansen L, Salmon D, Galasko D, Masliah E, Katzman R, DeTeresa R, Thal L, Pay MM, Hofstetter R, Klauber M, et al. (1990) The Lewy body variant of Alzheimer's disease: A clinical and pathologic entity. Neurology, 40, 1-8.

[6] Irizarry MC, Growdon W, Gomez-Isla T, Newell K, George JM, Clayton DF, \& Hyman BT (1998) Nigral and cortical 
Lewy bodies and dystrophic nigral neurites in Parkinson's disease and cortical Lewy body disease contain alphasynuclein immunoreactivity. J Neuropathol Exp Neurol, 57, 334-337.

[7] Wakabayashi K, Yoshimoto M, Tsuji S, \& Takahashi H (1998) Alpha-synuclein immunoreactivity in glial cytoplasmic inclusions in multiple system atrophy. Neurosci Lett, 249, 180-182.

[8] Lippa CF, Fujiwara H, Mann DM, Giasson B, Baba M, Schmidt ML, Nee LE, O'Connell B, Pollen DA, St GeorgeHyslop P, Ghetti B, Nochlin D, Bird TD, Cairns NJ, Lee VM, Iwatsubo T, \& Trojanowski JQ (1998) Lewy bodies contain altered alpha-synuclein in brains of many familial Alzheimer's disease patients with mutations in presenilin and amyloid precursor protein genes. Am J Pathol, 153, 1365-1370.

[9] Lippa CF, Schmidt ML, Lee VM, \& Trojanowski JQ (1999) Antibodies to alpha-synuclein detect Lewy bodies in many Down's syndrome brains with Alzheimer's disease. Ann Neurol, 45, 353-357.

[10] Arawaka S, Saito Y, Murayama S, \& Mori H (1998) Lewy body in neurodegeneration with brain iron accumulation type 1 is immunoreactive for alpha-synuclein. Neurology, 51, 887-889.

[11] Polymeropoulos MH, Lavedan C, Leroy E, Ide SE, Dehejia A, Dutra A, Pike B, Root H, Rubenstein. J, Boyer R, Stenroos ES, Chandrasekharappa S, Athanassiadou A, Papapetropoulos T, Johnson WG, Lazzarini AM, Duvoisin RC, Di Iorio G, Golbe LI, \&Nussbaum RL (1997) Mutation in the alpha-synuclein gene identified in families with Parkinson's disease. Science, 276, 2045-2047.

[12] Kruger R, Kuhn W, Muller T, Woitalla D, Graeber M, Kosel S, Przuntek H, Epplen JT, Schols L, \& Riess O (1998) Ala30Pro mutation in the gene encoding alpha-synuclein in Parkinson's disease. Nat Genet, 18, 106-108.

[13] Zarranz JJ, Alegre J, Gomez-Esteban JC, Lezcano E, Ros R, Ampuero I, Vidal L, Hoenicka J, Rodriguez O, Atares B, Llorens V, Gomez Tortosa E, del Ser T, Munoz DG, \& de Yebenes JG (2004) The new mutation, E46K, of alphasynuclein causes Parkinson and Lewy body dementia. Ann Neurol, 55, 164-173.

[14] Singleton AB, Farrer M, Johnson. J, Singleton A, Hague S, Kachergus J, Hulihan M, Peuralinna T, Dutra A, Nussbaum R, Lincoln S, Crawley A, Hanson M, Maraganore D, Adler C, Cookson MR, Muenter M, Baptista M, Miller D, Blancato J, Hardy J, \& Gwinn-Hardy K (2003) alpha-Synuclein locus triplication causes Parkinson's disease. Science, 302, 841.

[15] Ibanez P, Bonnet AM, Debarges B, Lohmann E, Tison F, Pollak P, Agid Y, Durr A, \& Brice A (2004) Causal relation between alpha-synuclein gene duplication and familial Parkinson's disease. Lancet, 364, 1169-1171.

[16] Chartier-Harlin MC, Kachergus. J, Roumier C, Mouroux V, Douay X, Lincoln S, Levecque C, Larvor L, Andrieux J, Hulihan M, Waucquier N, Defebvre L, Amouyel P, Farrer M, \& Destee A (2004) Alpha-synuclein locus duplication as a cause of familial Parkinson's disease. Lancet, 364, 11671169

[17] Nalls MA, Plagnol V, Hernandez DG, Sharma M, Sheerin UM, Saad M, Simon-Sanchez J, Schulte C, Lesage S, Sveinbjornsdottir S, Stefansson K, Martinez M, Hardy J, Heutink P, Brice A, Gasser T, Singleton AB, \& Wood NW (2011) Imputation of sequence variants for identification of genetic risks for Parkinson's disease: A meta-analysis of genome-wide association studies. Lancet, 377, 641649 .
[18] Satake W, Nakabayashi Y, Mizuta I, Hirota Y, Ito C, Kubo M, Kawaguchi T, Tsunoda T, Watanabe M, Takeda A, Tomiyama H, Nakashima K, Hasegawa K, Obata F, Yoshikawa T, Kawakami H, Sakoda S, Yamamoto M, Hattori N, Murata M, Nakamura Y, \& Toda T (2009) Genome-wide association study identifies common variants at four loci as genetic risk factors for Parkinson's disease. Nat Genet, 41, 1303-1307.

[19] Simon-Sanchez. J, Schulte C, Bras JM, Sharma M, Gibbs JR, Berg D, Paisan-Ruiz C, Lichtner P, Scholz SW, Hernandez DG, Kruger R, Federoff M, Klein C, Goate A, Perlmutter J, Bonin M, Nalls MA, Illig T, Gieger C, Houlden H, Steffens M, Okun MS, Racette BA, Cookson MR, Foote KD, Fernandez HH, Traynor BJ, Schreiber S, Arepalli S, Zonozi R, Gwinn K, van der Brug M, Lopez G, Chanock SJ, Schatzkin A, Park Y, Hollenbeck A, Gao J, Huang X, Wood NW, Lorenz D, Deuschl G, Chen H, Riess O, Hardy JA, Singleton AB, \& Gasser T (2009) Genome-wide association study reveals genetic risk underlying Parkinson's disease. Nat Genet, 41, 1308-1312.

[20] Conway KA, Lee SJ, Rochet JC, Ding TT, Williamson RE, \& Lansbury PT Jr (2000) Acceleration of oligomerization, not fibrillization, is a shared property of both alpha-synuclein mutations linked to early-onset Parkinson's disease: Implications for pathogenesis and therapy. Proc Natl Acad Sci U S A, 97, 571-576.

[21] Davidson WS, Jonas A, Clayton DF, \& George JM (1998) Stabilization of alpha-synuclein secondary structure upon binding to synthetic membranes. J Biol Chem, 273, 94439449.

[22] Weinreb PH, Zhen W, Poon AW, Conway KA, \& Lansbury PT Jr (1996) NACP, a protein implicated in Alzheimer's disease and learning, is natively unfolded. Biochemistry, 35, 13709-13715.

[23] Bartels T, Choi JG, \& Selkoe DJ (2011) alpha-Synuclein occurs physiologically as a helically folded tetramer that resists aggregation. Nature, 477, 107-110.

[24] Karpinar DP, Balija MB, Kugler S, Opazo F, Rezaei-Ghaleh N, Wender N, Kim HY, Taschenberger G, Falkenburger BH, Heise H, Kumar A, Riedel D, Fichtner L, Voigt A, Braus GH, Giller K, Becker S, Herzig A, Baldus M, Jackle H, Eimer S, Schulz JB, Griesinger C, \& Zweckstetter M (2009) Pre-fibrillar alpha-synuclein variants with impaired beta-structure increase neurotoxicity in Parkinson's disease models. EMBO J, 28, 3256-3268.

[25] Winner B, Jappelli R, Maji SK, Desplats PA, Boyer L, Aigner S, Hetzer C, Loher T, Vilar M, Campioni S, Tzitzilonis C, Soragni A, Jessberger S, Mira H, Consiglio A, Pham E, Masliah E, Gage FH, \& Riek R (2011) In vivo demonstration that alpha-synuclein oligomers are toxic. Proc Natl Acad Sci U S A 108, 4194-4199.

[26] Danzer KM, Haasen D, Karow AR, Moussaud S, Habeck M, Giese A, Kretzschmar H, Hengerer B, \& Kostka M (2007) Different species of alpha-synuclein oligomers induce calcium influx and seeding. $J$ Neurosci, 27, 9220-9232.

[27] Outeiro TF, Putcha P, Tetzlaff JE, Spoelgen R, Koker M, Carvalho F, Hyman BT, \& McLean PJ (2008) Formation of toxic oligomeric alpha-synuclein species in living cells. PLoS One, 3, e1867.

[28] Ebrahimi-Fakhari D, Cantuti-Castelvetri I, Fan Z, Rockenstein E, Masliah E, Hyman BT, McLean PJ, \& Unni VK (2011) Distinct Roles In Vivo for the Ubiquitin-Proteasome System and the Autophagy-Lysosomal Pathway in the Degradation of $\{$ alpha $\}$-Synuclein. J Neurosci, 31, 1450814520 . 
[29] Hartl FU, Bracher A, \& Hayer-Hartl M (2011) Molecular chaperones in protein folding and proteostasis. Nature, $\mathbf{4 7 5}$, 324-332.

[30] Morimoto RI (1993) Cells in stress: Transcriptional activation of heat shock genes. Science, 259, 1409-1410.

[31] Zou J, Guo Y, Guettouche T, Smith DF, \& Voellmy R (1998) Repression of heat shock transcription factor HSF1 activation by HSP90 (HSP90 complex) that forms a stresssensitive complex with HSF1. Cell, 94, 471-480.

[32] Mosser DD, Theodorakis NG, \& Morimoto RI (1988) Coordinate changes in heat shock element-binding activity and HSP70 gene transcription rates in human cells. Mol Cell Biol, 8, 4736-4744

[33] Morimoto RI (1998) Regulation of the heat shock transcriptional response: Cross talk between a family of heat shock factors, molecular chaperones, and negative regulators. Genes Dev, 12, 3788-3796.

[34] Shi Y, Mosser DD, \& Morimoto RI (1998) Molecular chaperones as HSF1-specific transcriptional repressors. Genes Dev, 12, 654-666.

[35] Ravagnan L, Gurbuxani S, Susin SA, Maisse C, Daugas E, Zamzami N, Mak T, Jaattela M, Penninger JM, Garrido C, \& Kroemer G (2001) Heat-shock protein 70 antagonizes apoptosis-inducing factor. Nat Cell Biol, 3, 839-843.

[36] Richter K, Haslbeck M, \& Buchner J (2010) The heat shock response: Life on the verge of death. Mol Cell, 40, 253-266.

[37] Whitesell L, \& Lindquist SL (2005) HSP90 and the chaperoning of cancer. Nat Rev Cancer, 5, 761-772.

[38] Macario AJ, \& Conway de Macario E (2005) Sick chaperones, cellular stress, and disease. $N$ Engl J Med, 353, 1489-1501

[39] Trepel J, Mollapour M, Giaccone G, \& Neckers L (2010) Targeting the dynamic HSP90 complex in cancer. Nat Rev Cancer, 10, 537-549.

[40] Muchowski PJ, \& Wacker JL (2005) Modulation of neurodegeneration by molecular chaperones. Nat Rev Neurosci, 6, 11-22.

[41] Benarroch EE (2011) Heat shock proteins: Multiple neuroprotective functions and implications for neurologic disease. Neurology, 76, 660-667.

[42] Kalia SK, Kalia LV, \& McLean PJ (2010) Molecular chaperones as rational drug targets for Parkinson's disease therapeutics. CNS Neurol Disord Drug Targets, 9, 741-753.

[43] Luo W, Sun W, Taldone T, Rodina A, \& Chiosis G (2010) Heat shock protein 90 in neurodegenerative diseases. Mol Neurodegener, 5, 24.

[44] Cummings CJ, Mancini MA, Antalffy B, DeFranco DB, Orr HT, \& Zoghbi HY (1998) Chaperone suppression of aggregation and altered subcellular proteasome localization imply protein misfolding in SCA1. Nat Genet, 19, 148154.

[45] Chai Y, Koppenhafer SL, Bonini NM, \& Paulson HL (1999) Analysis of the role of heat shock protein (Hsp) molecular chaperones in polyglutamine disease. JNeurosci, 19, 1033810347.

[46] Kazemi-Esfarjani P, \& Benzer S (2000) Genetic suppression of polyglutamine toxicity in Drosophila. Science, 287, 18371840.

[47] Cummings CJ, Sun Y, Opal P, Antalffy B, Mestril R, Orr HT, Dillmann WH, \& Zoghbi HY (2001) Over-expression of inducible HSP70 chaperone suppresses neuropathology and improves motor function in SCA1 mice. Hum Mol Genet, 10, 1511-1518

[48] McLean PJ, Kawamata H, Shariff S, Hewett J, Sharma N, Ueda K, Breakefield XO, \& Hyman BT (2002) TorsinA and heat shock proteins act as molecular chaperones: Suppression of alpha-synuclein aggregation. J Neurochem, $\mathbf{8 3}$, 846-854.

[49] Uryu K, Richter-Landsberg C, Welch W, Sun E, Goldbaum O, Norris EH, Pham CT, Yazawa I, Hilburger K, Micsenyi M, Giasson BI, Bonini NM, Lee VM, \& Trojanowski JQ (2006) Convergence of heat shock protein 90 with ubiquitin in filamentous alpha-synuclein inclusions of alpha-synucleinopathies. Am J Pathol, 168, 947-961.

[50] Auluck PK, Chan HY, Trojanowski JQ, Lee VM, \& Bonini NM (2002) Chaperone suppression of alpha-synuclein toxicity in a Drosophila model for Parkinson's disease. Science, 295, 865-868.

[51] Leverenz JB, Umar I, Wang Q, Montine TJ, McMillan PJ, Tsuang DW, Jin. J, Pan C, Shin J, Zhu D, \& Zhang J (2007) Proteomic identification of novel proteins in cortical Lewy bodies. Brain Pathol 17, 139-145.

[52] Bonini NM (2002) Chaperoning brain degeneration. Proc Natl Acad Sci U S A, 99(Suppl 4), 16407-16411.

[53] Helfand SL (2002) Neurobiology. Chaperones take fight. Science, 295, 809-810.

[54] Flower TR, Chesnokova LS, Froelich CA, Dixon C, \& Witt SN (2005) Heat shock prevents alpha-synuclein-induced apoptosis in a yeast model of Parkinson's disease. $\mathrm{J} \mathrm{Mol}$ Biol, 351, 1081-1100.

[55] Tantucci M, Mariucci G, Taha E, Spaccatini C, Tozzi A, Luchetti E, Calabresi P, \& Ambrosini MV (2009) Induction of heat shock protein 70 reduces the alteration of striatal electrical activity caused by mitochondrial impairment. Neuroscience, 163, 735-740.

[56] Fan GH, Zhou HY, Yang H, \& Chen SD (2006) Heat shock proteins reduce alpha-synuclein aggregation induced by MPP+ in SK-N-SH cells. FEBS Lett, 580, 3091-3098.

[57] Quigney DJ, Gorman AM, \& Samali A (2003) Heat shock protects PC12 cells against MPP+toxicity. Brain Res, 993, 133-139.

[58] Zhou Y, Gu G, Goodlett DR, Zhang T, Pan C, Montine TJ, Montine KS, Aebersold RH, \& Zhang J (2004) Analysis of alpha-synuclein-associated proteins by quantitative proteomics. J Biol Chem, 279, 39155-39164.

[59] Kuhn K, Wellen. J, Link N, Maskri L, Lubbert H, \& Stichel CC (2003) The mouse MPTP model: Gene expression changes in dopaminergic neurons. Eur J Neurosci, 17, $1-12$.

[60] St Martin JL, Klucken. J, Outeiro TF, Nguyen P, KellerMcGandy C, Cantuti-Castelvetri I, Grammatopoulos TN, Standaert DG, Hyman BT, \& McLean PJ (2007) Dopaminergic neuron loss and up-regulation of chaperone protein mRNA induced by targeted over-expression of alphasynuclein in mouse substantia nigra. J Neurochem, 100, 1449-1457.

[61] Outeiro TF, Klucken J, Strathearn KE, Liu F, Nguyen P, Rochet JC, Hyman BT, \& McLean PJ (2006) Small heat shock proteins protect against alpha-synuclein-induced toxicity and aggregation. Biochem Biophys Res Commun, 351, 631-638.

[62] Klucken J, Shin Y, Hyman BT, \& McLean PJ (2004) A single amino acid substitution differentiates Hsp70dependent effects on alpha-synuclein degradation and toxicity. Biochem Biophys Res Commun, 325, 367-373.

[63] Klucken J, Shin Y, Masliah E, Hyman BT, \& McLean PJ (2004) Hsp70 Reduces alpha-Synuclein aggregation and Toxicity. J Biol Chem, 279, 25497-25502.

[64] Opazo F, Krenz A, Heermann S, Schulz JB, \& Falkenburger BH (2008) Accumulation and clearance of alpha-synuclein 
aggregates demonstrated by time-lapse imaging. $J \mathrm{Neu}$ rochem, 106, 529-540.

[65] Zourlidou A, Payne Smith MD, \& Latchman DS (2004) HSP27 but not HSP70 has a potent protective effect against alpha-synuclein-induced cell death in mammalian neuronal cells. J Neurochem, 88, 1439-1448.

[66] Lindersson E, Beedholm R, Hojrup P, Moos T, Gai W, Hendil KB, \& Jensen PH (2004) Proteasomal inhibition by alphasynuclein filaments and oligomers. J Biol Chem, 279, 1292412934.

[67] Shimshek DR, Mueller M, Wiessner C, Schweizer T, \& van der Putten PH (2010) The HSP70 molecular chaperone is not beneficial in a mouse model of alpha-synucleinopathy. PLoS One, 5, e10014.

[68] Dedmon MM, Christodoulou J, Wilson MR, \& Dobson CM (2005) Heat shock protein 70 inhibits alpha-synuclein fibril formation via preferential binding to prefibrillar species. $J$ Biol Chem, 280, 14733-14740.

[69] Pemberton S, Madiona K, Pieri L, Kabani M, Bousset L, \& Melki R (2011) Hsc70 Protein Interaction with Soluble and Fibrillar alpha-Synuclein. J Biol Chem, 286, 34690-34699.

[70] Luk KC, Mills IP, Trojanowski JQ, \& Lee VM (2008) Interactions between Hsp70 and the hydrophobic core of alpha-synuclein inhibit fibril assembly. Biochemistry, 47, 12614-12625.

[71] Huang C, Cheng H, Hao S, Zhou H, Zhang X, Gao. J, Sun QH, Hu H, \& Wang CC (2006) Heat shock protein 70 inhibits alpha-synuclein fibril formation via interactions with diverse intermediates. J Mol Biol, 364, 323-336

[72] Klucken J, Outeiro TF, Nguyen P, McLean PJ, \& Hyman BT (2006) Detection of novel intracellular alpha-synuclein oligomeric species by fluorescence lifetime imaging. FASEB $J$, 20, 2050-2057.

[73] Danzer KM, Ruf WP, Putcha P, Joyner D, Hashimoto T Glabe C, Hyman BT, \& McLean PJ (2011) Heat-shock protein 70 modulates toxic extracellular alpha-synuclein oligomers and rescues trans-synaptic toxicity. FASEB J, 25, 326-336.

[74] Falsone SF, Kungl AJ, Rek A, Cappai R, \& Zangger K (2009) The molecular chaperone Hsp90 modulates intermediate steps of amyloid assembly of the Parkinson-related protein alpha-synuclein. J Biol Chem, 284, 31190-31199.

[75] Calderwood SK, Murshid A, \& Prince T (2009) The shock of aging: Molecular chaperones and the heat shock response in longevity and aging-a mini-review. Gerontology, 55, 550558.

[76] Koga H, Kaushik S, \& Cuervo AM (2011) Protein homeostasis and aging: The importance of exquisite quality control. Ageing Res Rev, 10, 205-215.

[77] Wu YR, Wang CK, Chen CM, Hsu Y, Lin SJ, Lin YY, Fung HC, Chang KH, \& Lee-Chen GJ (2004) Analysis of heat-shock protein 70 gene polymorphisms and the risk of Parkinson's disease. Hum Genet, 114, 236-241.

[78] Iwaki T, Wisniewski T, Iwaki A, Corbin E, Tomokane N, Tateishi J, \& Goldman JE (1992) Accumulation of alpha B-crystallin in central nervous system glia and neurons in pathologic conditions. Am J Pathol, 140, 345-356.

[79] Braak H, Del Tredici K, Sandmann-Kiel D, Rub U, \& Schultz C (2001) Nerve cells expressing heat-shock proteins in Parkinson's disease. Acta Neuropathol, 102, 449-454.

[80] Cantuti-Castelvetri I, Klucken J, Ingelsson M, Ramasamy K, McLean PJ, Frosch MP, Hyman BT, \& Standaert DG (2005) Alpha-synuclein and chaperones in dementia with Lewy bodies. J Neuropathol Exp Neurol, 64, 1058-1066.
[81] Klucken J, Ingelsson M, Shin Y, Irizarry MC, HedleyWhyte ET, Frosch M, Growdon J, McLean P, \& Hyman BT (2006) Clinical and biochemical correlates of insoluble alpha-synuclein in dementia with Lewy bodies. Acta Neuropathol, 111, 101-108.

[82] Alvarez-Erviti L, Rodriguez-Oroz MC, Cooper JM, Caballero C, Ferrer I, Obeso JA, \& Schapira AH (2010) Chaperone-mediated autophagy markers in Parkinson disease brains. Arch Neurol, 67, 1464-1472.

[83] Hauser MA, Li YJ, Xu H, Noureddine MA, Shao YS, Gullans SR, Scherzer CR, Jensen RV, McLaurin AC, Gibson JR, Scott BL, Jewett RM, Stenger JE, Schmechel DE, Hulette CM, \& Vance JM (2005) Expression profiling of substantia nigra in Parkinson disease, progressive supranuclear palsy, and frontotemporal dementia with parkinsonism. Arch Neurol, 62, 917-921.

[84] Jin J, Hulette C, Wang Y, Zhang T, Pan C, Wadhwa R, \& Zhang J (2006) Proteomic identification of a stress protein, mortalin/mthsp70/GRP75: Relevance to Parkinson disease. Mol Cell Proteomics, 5, 1193-1204.

[85] Chu Y, Dodiya H, Aebischer P, Olanow CW, \& Kordower JH (2009) Alterations in lysosomal and proteasomal markers in Parkinson's disease: Relationship to alphasynuclein inclusions. Neurobiol Dis, 35, 385-398.

[86] Hinault MP, Cuendet AF, Mattoo RU, Mensi M, Dietler G, Lashuel HA, \& Goloubinoff P (2010) Stable alpha-synuclein oligomers strongly inhibit chaperone activity of the Hsp70 system by weak interactions with J-domain co-chaperones. J Biol Chem, 285, 38173-38182.

[87] Winklhofer KF, Henn IH, Kay-Jackson PC, Heller U, \& Tatzelt J (2003) Inactivation of parkin by oxidative stress and C-terminal truncations: A protective role of molecular chaperones. J Biol Chem, 278, 47199-47208.

[88] Kalia SK, Lee S, Smith PD, Liu L, Crocker SJ, Thorarinsdottir TE, Glover JR, Fon EA, Park DS, \& Lozano AM (2004) BAG5 inhibits parkin and enhances dopaminergic neuron degeneration. Neuron, 44, 931-945.

[89] Rose JM, Novoselov SS, Robinson PA, \& Cheetham ME (2011) Molecular chaperone-mediated rescue of mitophagy by a Parkin RING1 domain mutant. Hum Mol Genet, 20, 16-27.

[90] Yang H, Zhou X, Liu X, Yang L, Chen Q, Zhao D, Zuo J, \& Liu W (2011) Mitochondrial dysfunction induced by knockdown of mortalin is rescued by Parkin. Biochem Biophys Res Commun, 410, 114-120.

[91] Batelli S, Albani D, Rametta R, Polito L, Prato F, Pesaresi M, Negro A, \& Forloni G (2008) DJ-1 modulates alphasynuclein aggregation state in a cellular model of oxidative stress: Relevance for Parkinson's disease and involvement of HSP70. PLoS One, 3, e1884.

[92] Li HM, Niki T, Taira T, Iguchi-Ariga SM, \& Ariga H (2005) Association of DJ-1 with chaperones and enhanced association and colocalization with mitochondrial Hsp70 by oxidative stress. Free Radic Res, 39, 1091-1099.

[93] Moore DJ, Zhang L, Troncoso. J, Lee MK, Hattori N, Mizuno Y, Dawson TM, \& Dawson VL (2005) Association of DJ-1 and parkin mediated by pathogenic DJ-1 mutations and oxidative stress. Hum Mol Genet, 14, 71-84.

[94] Ardley HC, Scott GB, Rose SA, Tan NG, \& Robinson PA (2004) UCH-L1 aggresome formation in response to proteasome impairment indicates a role in inclusion formation in Parkinson's disease. J Neurochem, 90, 379391.

[95] Kabuta T, Furuta A, Aoki S, Furuta K, \& Wada K (2008) Aberrant interaction between Parkinson disease-associated 
mutant UCH-L1 and the lysosomal receptor for chaperonemediated autophagy. J Biol Chem, 283, 23731-23738.

[96] Lin W, \& Kang UJ (2008) Characterization of PINK1 processing, stability, and subcellular localization. JNeurochem, 106, 464-474.

[97] Moriwaki Y, Kim YJ, Ido Y, Misawa H, Kawashima K, Endo S, \& Takahashi R (2008) L347P PINK1 mutant that fails to bind to Hsp90/Cdc37 chaperones is rapidly degraded in a proteasome-dependent manner. Neurosci Res, 61, 43-48.

[98] Takayama S, Bimston DN, Matsuzawa S, Freeman BC, Aime-Sempe C, Xie Z, Morimoto RI, \& Reed JC (1997) BAG-1 modulates the chaperone activity of Hsp70/Hsc70. EMBO J, 16, 4887-4896.

[99] Nollen EA, Brunsting JF, Song J, Kampinga HH, Morimoto RI (2000) Bag1 functions in vivo as a negative regulator of Hsp70 chaperone activity. Mol Cell Biol, 20, 1083-1088.

[100] Nollen EA, Kabakov AE, Brunsting JF, Kanon B, Hohfeld J, \& Kampinga HH (2001) Modulation of in vivo HSP70 chaperone activity by Hip and Bag-1. J Biol Chem, 276, 4677-4682.

[101] Behl C (2011) BAG3 and friends: Co-chaperones in selective autophagy during aging and disease. Autophagy, 7, 795-798.

[102] Rosati A, Graziano V, De Laurenzi V, Pascale M, \& Turco MC (2011) BAG3: A multifaceted protein that regulates major cell pathways. Cell Death Dis, 2, e141.

[103] Kalia LV, Kalia SK, Chau H, Lozano AM, Hyman BT, \& McLean PJ (2011) Ubiquitinylation of alpha-synuclein by carboxyl terminus Hsp70-interacting protein (CHIP) is regulated by Bcl-2-associated athanogene 5 (BAG5). PLoS One, 6, e14695.

[104] Kampinga HH, Kanon B, Salomons FA, Kabakov AE, \& Patterson C (2003) Overexpression of the cochaperone CHIP enhances Hsp70-dependent folding activity in mammalian cells. Mol Cell Biol, 23, 4948-4958.

[105] Jiang J, Ballinger CA, Wu Y, Dai Q, Cyr DM, Hohfeld J, Patterson C (2001) CHIP is a U-box-dependent E3 ubiquitin ligase: Identification of Hsc70 as a target for ubiquitylation. J Biol Chem, 276, 42938-42944.

[106] Murata S, Minami Y, Minami M, Chiba T, \& Tanaka K (2001) CHIP is a chaperone-dependent E3 ligase that ubiquitylates unfolded protein. EMBO Rep, 2, 1133-1138.

[107] Connell P, Ballinger CA, Jiang J, Wu Y, Thompson LJ, Hohfeld J, \& Patterson C (2001) The co-chaperone CHIP regulates protein triage decisions mediated by heat-shock proteins. Nat Cell Biol 3, 93-96.

[108] Meacham GC, Patterson C, Zhang W, Younger JM, \& Cyr DM (2001) The Hsc70 co-chaperone CHIP targets immature CFTR for proteasomal degradation. Nat Cell Biol, 3, 100105.

[109] Imai Y, Soda M, Hatakeyama S, Akagi T, Hashikawa T, Nakayama KI, \& Takahashi R (2002) CHIP is associated with Parkin, a gene responsible for familial Parkinson's disease, and enhances its ubiquitin ligase activity. Mol Cell, 10, 55-67.

[110] Shin Y, Klucken. J, Patterson C, Hyman BT, \& McLean PJ (2005) The co-chaperone carboxyl terminus of Hsp70-interacting protein (CHIP) mediates alpha-synuclein degradation decisions between proteasomal and lysosomal pathways. J Biol Chem, 280, 23727-23734.

[111] Petrucelli L, Dickson D, Kehoe K \& Taylor J, Snyder H, Grover A, De Lucia M, McGowan E, Lewis J, Prihar G, Kim J, Dillmann WH, Browne SE, Hall A, Voellmy R, Tsuboi Y, Dawson TM, Wolozin B, Hardy J, \& Hutton M (2004)
CHIP and Hsp70 regulate tau ubiquitination, degradation and aggregation. Hum Mol Genet, 13, 703-714.

[112] Tetzlaff JE, Putcha P, Outeiro TF, Ivanov A, Berezovska O, Hyman BT, \& McLean PJ (2008) CHIP targets toxic alpha-Synuclein oligomers for degradation. J Biol Chem, 283, 17962-17968.

[113] Ding X, \& Goldberg MS (2009) Regulation of LRRK2 stability by the E3 ubiquitin ligase CHIP. PLoS One, 4, e5949.

[114] Ko HS, Bailey R, Smith WW, Liu Z, Shin JH, Lee YI, Zhang YJ, Jiang H, Ross CA, Moore DJ, Patterson C, Petrucelli L, Dawson TM, \& Dawson VL (2009) CHIP regulates leucine-rich repeat kinase-2 ubiquitination, degradation, and toxicity. Proc Natl Acad Sci U S A, 106, 2897-2902.

[115] Gloeckner CJ, Kinkl N, Schumacher A, Braun RJ, O’Neill E, Meitinger T, Kolch W, Prokisch H, \& Ueffing M (2006) The Parkinson disease causing LRRK2 mutation I2020T is associated with increased kinase activity. Hum Mol Genet, 15, 223-232.

[116] Dachsel JC, Taylor JP, Mok SS, Ross OA, Hinkle KM, Bailey RM, Hines JH, Szutu J, Madden B, Petrucelli L, \& Farrer MJ (2007) Identification of potential protein interactors of Lrrk2. Parkinsonism Relat Disord, 13, 382385.

[117] Scherzer CR, Eklund AC, Morse LJ, Liao Z, Locascio JJ, Fefer D, Schwarzschild MA, Schlossmacher MG, Hauser MA, Vance JM, Sudarsky LR, Standaert DG, Growdon JH, Jensen RV, \& Gullans SR (2007) Molecular markers of early Parkinson's disease based on gene expression in blood. Proc Natl Acad Sci U S A, 104, 955-960.

[118] Roodveldt C, Bertoncini CW, Andersson A, van der Goot AT, Hsu ST, Fernandez-Montesinos R, de Jong J, van Ham TJ, Nollen EA, Pozo D, Christodoulou J, \& Dobson CM (2009) Chaperone proteostasis in Parkinson's disease: Stabilization of the Hsp70/alpha-synuclein complex by Hip. EMBO J, 28, 3758-3770.

[119] Olanow CW, Kieburtz K, \& Schapira AH (2008) Why have we failed to achieve neuroprotection in Parkinson's disease? Ann Neurol, 64 (Suppl 2), S101-S110.

[120] Olanow CW (2009) Can we achieve neuroprotection with currently available anti-parkinsonian interventions? Neurology, 72, S59-S64.

[121] Hung AY, \& Schwarzschild MA (2007) Clinical trials for neuroprotection in Parkinson's disease: Overcoming angst and futility? Curr Opin Neurol, 20, 477-483.

[122] Prodromou C, Roe SM, O'Brien R, Ladbury JE, Piper PW, \& Pearl LH (1997) Identification and structural characterization of the ATP/ADP-binding site in the Hsp90 molecular chaperone. Cell, 90, 65-75.

[123] Schneider C, Sepp-Lorenzino L, Nimmesgern E, Ouerfelli O, Danishefsky S, Rosen N, \& Hartl FU (1996) Pharmacologic shifting of a balance between protein refolding and degradation mediated by Hsp90. Proc Natl Acad Sci U S A, 93, 14536-14541.

[124] Taldone T, Gozman A, Maharaj R, \& Chiosis G (2008) Targeting Hsp90: Small-molecule inhibitors and their clinical development. Curr Opin Pharmacol, 8, 370-374.

[125] Kim YS, Alarcon SV, Lee S, Lee MJ, Giaccone G, Neckers L, \& Trepel JB (2009) Update on Hsp90 inhibitors in clinical trial. Curr Top Med Chem, 9, 1479-1492.

[126] Whitesell L, Mimnaugh EG, De Costa B, Myers CE, \& Neckers LM (1994) Inhibition of heat shock protein HSP90-pp60v-src heteroprotein complex formation by benzoquinone ansamycins: Essential role for stress proteins in oncogenic transformation. Proc Natl Acad Sci U S A, 91, 8324-8328. 
[127] McLean PJ, Klucken. J, Shin Y, \& Hyman BT (2004) Geldanamycin induces Hsp70 and prevents alpha-synuclein aggregation and toxicity in vitro. Biochem Biophys Res Commun, 321, 665-669.

[128] Emmanouilidou E, Stefanis L, \& Vekrellis K (2010) Cellproduced alpha-synuclein oligomers are targeted to, and impair, the 26S proteasome. Neurobiol Aging, 31, 953-968.

[129] Liu J, Zhang JP, Shi M, Quinn T, Bradner J, Beyer R, Chen S, \& Zhang J (2009) Rab11a and HSP90 regulate recycling of extracellular alpha-synuclein. J Neurosci, 29, 14801485 .

[130] Angot E, Steiner JA, Hansen C, Li JY, \& Brundin P (2010) Are synucleinopathies prion-like disorders? Lancet Neurol, 9, 1128-1138

[131] Gerges NZ, Tran IC, Backos DS, Harrell JM, Chinkers M, Pratt WB, \& Esteban JA (2004) Independent functions of hsp90 in neurotransmitter release and in the continuous synaptic cycling of AMPA receptors. J Neurosci, 24, 4758-4766.

[132] Xiao N, Callaway CW, Lipinski CA, Hicks SD, \& DeFranco DB (1999) Geldanamycin provides posttreatment protection against glutamate-induced oxidative toxicity in a mouse hippocampal cell line. J Neurochem, 72, 95-101.

[133] Auluck PK, \& Bonini NM (2002) Pharmacological prevention of Parkinson disease in Drosophila. Nat Med, 8, 1185-1186.

[134] Auluck PK, Meulener MC, \& Bonini NM (2005) Mechanisms of Suppression of $\{$ alpha $\}$-Synuclein Neurotoxicity by Geldanamycin in Drosophila. J Biol Chem, 280, 2873 2878.

[135] Shen HY, He JC, Wang Y, Huang QY, \& Chen JF (2005) Geldanamycin induces heat shock protein 70 and protects against MPTP-induced dopaminergic neurotoxicity in mice. J Biol Chem, 280, 39962-39969.

[136] Hay DG, Sathasivam K, Tobaben S, Stahl B, Marber M, Mestril R, Mahal A, Smith DL, Woodman B, \& Bates GP (2004) Progressive decrease in chaperone protein levels in a mouse model of Huntington's disease and induction of stress proteins as a therapeutic approach. Hum Mol Genet, 13, 1389-1405.

[137] Sittler A, Lurz R, Lueder G, Priller J, Lehrach H, HayerHartl MK, Hartl FU, \& Wanker EE (2001) Geldanamycin activates a heat shock response and inhibits huntingtin aggregation in a cell culture model of Huntington's disease. Hum Mol Genet, 10, 1307-1315.

[138] Thomas M, Harrell JM, Morishima Y, Peng HM, Pratt WB, \& Lieberman AP (2006) Pharmacologic and genetic inhibition of hsp90-dependent trafficking reduces aggregation and promotes degradation of the expanded glutamine androgen receptor without stress protein induction. Hum Mol Genet, 15, 1876-1883.

[139] Batulan Z, Taylor DM, Aarons RJ, Minotti S, Doroudchi MM, Nalbantoglu J, \& Durham HD (2006) Induction of multiple heat shock proteins and neuroprotection in a primary culture model of familial amyotrophic lateral sclerosis. Neurobiol Dis, 24, 213-225.

[140] Tradewell ML, Cooper LA, Minotti S, \& Durham HD (2011) Calcium dysregulation, mitochondrial pathology and protein aggregation in a culture model of amyotrophic lateral sclerosis: Mechanistic relationship and differential sensitivity to intervention. Neurobiol Dis, 42, 265-275.

[141] Supko JG, Hickman RL, Grever MR, \& Malspeis L (1995) Preclinical pharmacologic evaluation of geldanamycin as an antitumor agent. Cancer Chemother Pharmacol, 36, $305-$ 315 .
[142] Egorin MJ, Zuhowski EG, Rosen DM, Sentz DL, Covey JM, \& Eiseman JL (2001) Plasma pharmacokinetics and tissue distribution of 17-(allylamino)-17demethoxygeldanamycin (NSC 330507) in CD2F1 mice1. Cancer Chemother Pharmacol, 47, 291-302.

[143] Schulte TW, \& Neckers LM (1998) The benzoquinone ansamycin 17-allylamino-17-demethoxygeldanamycin binds to HSP90 and shares important biologic activities with geldanamycin. Cancer Chemother Pharmacol, 42, 273-279.

[144] Putcha P, Danzer KM, Kranich LR, Scott A, Silinski M, Mabbett S, Hicks CD, Veal JM, Steed PM, Hyman BT, \& McLean PJ (2010) Brain-permeable small-molecule inhibitors of Hsp90 prevent alpha-synuclein oligomer formation and rescue alpha-synuclein-induced toxicity. $J$ Pharmacol Exp Ther, 332, 849-857.

[145] Riedel M, Goldbaum O, Schwarz L, Schmitt S, \& RichterLandsberg C (2010) 17-AAG induces cytoplasmic alphasynuclein aggregate clearance by induction of autophagy. PLoS One, 5, e8753.

[146] Fujikake N, Nagai Y, Popiel HA, Okamoto Y, Yamaguchi M, \& Toda T (2008) Heat shock transcription factor 1-activating compounds suppress polyglutamine-induced neurodegeneration through induction of multiple molecular chaperones. J Biol Chem, 283, 26188-26197.

[147] Waza M, Adachi H, Katsuno M, Minamiyama M, Sang C, Tanaka F, Inukai A, Doyu M, \& Sobue G (2005) 17-AAG, an Hsp90 inhibitor, ameliorates polyglutaminemediated motor neuron degeneration. Nat Med, 11, 10881095.

[148] Chandarlapaty S, Sawai A, Ye Q, Scott A, Silinski M, Huang K, Fadden P, Partdrige J, Hall S, Steed P, Norton L, Rosen N, \& Solit DB (2008) SNX2112, a synthetic heat shock protein 90 inhibitor, has potent antitumor activity against HER kinase-dependent cancers. Clin Cancer Res, 14, 240248.

[149] Okawa Y, Hideshima T, Steed P, Vallet S, Hall S, Huang K, Rice J, Barabasz A, Foley B, Ikeda H, Raje N, Kiziltepe T, Yasui H, Enatsu S, \& Anderson KC (2009) SNX-2112, a selective Hsp90 inhibitor, potently inhibits tumor cell growth, angiogenesis, and osteoclastogenesis in multiple myeloma and other hematologic tumors by abrogating signaling via Akt and ERK. Blood, 113, 846-855.

[150] Kalmar B, Novoselov S, Gray A, Cheetham ME, Margulis B, \& Greensmith L (2008) Late stage treatment with arimoclomol delays disease progression and prevents protein aggregation in the SOD1 mouse model of ALS. $\mathrm{J} \mathrm{Neu-}$ rochem, 107, 339-350.

[151] Kieran D, Kalmar B, Dick JR, Riddoch-Contreras J, Burnstock G, \& Greensmith L (2004) Treatment with arimoclomol, a coinducer of heat shock proteins, delays disease progression in ALS mice. Nat Med, 10, 402-405.

[152] Cudkowicz ME, Shefner JM, Simpson E, Grasso D, Yu H, Zhang H, Shui A, Schoenfeld D, Brown RH, Wieland S, \& Barber JR (2008) Arimoclomol at dosages up to 300mg/day is well tolerated and safe in amyotrophic lateral sclerosis. Muscle Nerve, 38, 837-844.

[153] Traynor BJ, Bruijn L, Conwit R, Beal F, O’Neill G, Fagan SC, \& Cudkowicz ME (2006) Neuroprotective agents for clinical trials in ALS: A systematic assessment. Neurology, 67, 20-27.

[154] Benn SC, \& Brown RH Jr (2004) Putting the heat on ALS. Nat Med, 10, 345-347.

[155] Kalmar B, \& Greensmith L (2009) Activation of the heat shock response in a primary cellular model of motoneuron 
neurodegeneration-evidence for neuroprotective and neurotoxic effects. Cell Mol Biol Lett, 14, 319-335.

[156] Vigh L, Literati PN, Horvath I, Torok Z, Balogh G, Glatz A, Kovacs E, Boros I, Ferdinandy P, Farkas B, Jaszlits L, Jednakovits A, Koranyi L, \& Maresca B (1997) Bimoclomol: A nontoxic, hydroxylamine derivative with stress proteininducing activity and cytoprotective effects. Nat Med, $\mathbf{3}$, $1150-1154$

[157] Nanasi PP, \& Jednakovits A (2001) Multilateral in vivo and in vitro protective effects of the novel heat shock protein coinducer, bimoclomol: Results of preclinical studies. Cardiovasc Drug Rev, 19, 133-151.

[158] Hargitai J, Lewis H, Boros I, Racz T, Fiser A, Kurucz I, Benjamin I, Vigh L, Penzes Z, Csermely P, Latchman DS, (2003) Bimoclomol, a heat shock protein co-inducer, acts by the prolonged activation of heat shock factor-1. Biochem Biophys Res Commun, 307, 689-695.

[159] Neef DW, Turski ML, \& Thiele DJ (2010) Modulation of heat shock transcription factor 1 as a therapeutic target for small molecule intervention in neurodegenerative disease. PLoS Biol, $\mathbf{8}$, e1000291.

[160] Westerheide SD, Bosman JD, Mbadugha BN, Kawahara TL, Matsumoto G, Kim S, Gu W, Devlin JP, Silverman RB, \& Morimoto RI (2004) Celastrols as inducers of the heat shock response and cytoprotection. J Biol Chem, 279, 56053-56060.

[161] Salminen A, Lehtonen M, Paimela T, \& Kaarniranta K (2010) Celastrol: Molecular targets of Thunder God Vine. Biochem Biophys Res Commun, 394, 439-442.

[162] Cleren C, Calingasan NY, Chen J, \& Beal MF (2005) Celastrol protects against MPTP- and 3-nitropropionic acidinduced neurotoxicity. J Neurochem, 94, 995-1004.

[163] Faust K, Gehrke S, Yang Y, Yang L, Beal MF, \& Lu B (2009) Neuroprotective effects of compounds with antioxidant and anti-inflammatory properties in a Drosophila model of Parkinson's disease. BMC Neurosc, 10, 109.

[164] Kiaei M, Kipiani K, Petri S, Chen J, Calingasan NY, \& Beal MF (2005) Celastrol blocks neuronal cell death and extends life in transgenic mouse model of amyotrophic lateral sclerosis. Neurodegener Dis, 2, 246-254.

[165] Wang J, Gines S, MacDonald ME, \& Gusella JF (2005) Reversal of a full-length mutant huntingtin neuronal cell phenotype by chemical inhibitors of polyglutaminemediated aggregation. BMC Neurosci $\mathbf{6}, 1$.

[166] Zhang YQ, \& Sarge KD (2007) Celastrol inhibits polyglutamine aggregation and toxicity though induction of the heat shock response. J Mol Med, 85, 1421-1428.

[167] Uchida S, Fujiki M, Nagai Y, Abe T, \& Kobayashi H (2006) Geranylgeranylacetone, a noninvasive heat shock protein inducer, induces protein kinase $\mathrm{C}$ and leads to neuroprotection against cerebral infarction in rats. Neurosci Lett, 396, 220-224.

[168] Fujiki M, Hikawa T, Abe T, Uchida S, Morishige M, Sugita $\mathrm{K}$, \& Kobayashi H (2006) Role of protein kinase C in neuroprotective effect of geranylgeranylacetone, a noninvasive inducing agent of heat shock protein, on delayed neuronal death caused by transient ischemia in rats. J Neurotrauma, 23, 1164-1178

[169] Nagai Y, Fujiki M, Inoue R, Uchida S, Abe T, Kobayashi $\mathrm{H}$, \& Cetinalp NE (2005) Neuroprotective effect of geranylgeranylacetone, a noninvasive heat shock protein inducer, on cerebral infarction in rats. Neurosci Lett, 374, 183188.

[170] Sinn DI, Chu K, Lee ST, Song EC, Jung KH, Kim EH, Park DK, Kang KM, Kim M, \& Roh JK (2007) Pharmacolog- ical induction of heat shock protein exerts neuroprotective effects in experimental intracerebral hemorrhage. Brain Res, 1135, 167-176.

[171] Katsuno M, Sang C, Adachi H, Minamiyama M, Waza M, Tanaka F, Doyu M, \& Sobue G (2005) Pharmacological induction of heat-shock proteins alleviates polyglutaminemediated motor neuron disease. Proc Natl Acad Sci U S A, 102, 16801-16806.

[172] Marinova Z, Ren M, Wendland JR, Leng Y, Liang MH, Yasuda S, Leeds P, \& Chuang DM (2009) Valproic acid induces functional heat-shock protein 70 via Class I histone deacetylase inhibition in cortical neurons: A potential role of Sp1 acetylation. J Neurochem, 111, 976-987.

[173] Wang JF, Azzam JE, \& Young LT (2003) Valproate inhibits oxidative damage to lipid and protein in primary cultured rat cerebrocortical cells. Neuroscience, 116, 485-489.

[174] Leng Y, Marinova Z, Reis-Fernandes MA, Nau H, \& Chuang DM (2010) Potent neuroprotective effects of novel structural derivatives of valproic acid: Potential roles of HDAC inhibition and HSP70 induction. Neurosci Lett, 476, 127-132.

[175] Ren M, Leng Y, Jeong M, Leeds PR, \& Chuang DM (2004) Valproic acid reduces brain damage induced by transient focal cerebral ischemia in rats: Potential roles of histone deacetylase inhibition and heat shock protein induction. $J$ Neurochem, 89, 1358-1367.

[176] Pan T, Li X, Xie W, Jankovic J, \& Le W (2005) Valproic acid-mediated Hsp70 induction and anti-apoptotic neuroprotection in SH-SY5Y cells. FEBS Lett, 579, 6716-6720.

[177] Monti B, Gatta V, Piretti F, Raffaelli SS, \& Virgili M (2010) Contestabile A. Valproic acid is neuroprotective in the rotenone rat model of Parkinson's disease: Involvement of alpha-synuclein. Neurotox Res, 17, 130-141.

[178] Roy A, \& Pahan K (2011) Prospects of statins in Parkinson disease. Neuroscientist, 17, 244-255.

[179] Brouet A, Sonveaux P, Dessy C, Moniotte S, Balligand JL, \& Feron O (2001) Hsp90 and caveolin are key targets for the proangiogenic nitric oxide-mediated effects of statins. Circ Res, 89, 866-873.

[180] Kretz A, Schmeer C, Tausch S, \& Isenmann S (2006) Simvastatin promotes heat shock protein 27 expression and Akt activation in the rat retina and protects axotomized retinal ganglion cells in vivo. Neurobiol Dis, 21, 421-430.

[181] Wang X, Tokuda H, Hatakeyama D, Hirade K, Niwa M, Ito H, Kato K, \& Kozawa O (2003) Mechanism of simvastatin on induction of heat shock protein in osteoblasts. Arch Biochem Biophys, 415, 6-13.

[182] Jain NK, \& Roy I (2009) Effect of trehalose on protein structure. Protein Sci, 18, 24-36.

[183] Tanaka M, Machida Y, Niu S, Ikeda T, Jana NR, Doi H, Kurosawa M, Nekooki M, \& Nukina N (2004) Trehalose alleviates polyglutamine-mediated pathology in a mouse model of Huntington disease. Nat Med, 10, 148-154.

[184] Sarkar S, Davies JE, Huang Z, Tunnacliffe A, \& Rubinsztein DC (2007) Trehalose, a novel mTOR-independent autophagy enhancer, accelerates the clearance of mutant huntingtin and alpha-synuclein. $J$ Biol Chem, 282, 56415652 .

[185] Casarejos MJ, Solano RM, Gomez A, Perucho J, de Yebenes JG, \& Mena MA (2011) The accumulation of neurotoxic proteins, induced by proteasome inhibition, is reverted by trehalose, an enhancer of autophagy, in human neuroblastoma cells. Neurochem Int, 58, 512520 .

[186] Bjorklund T, \& Kordower JH (2010) Gene therapy for Parkinson's disease. Mov Disord, 25 (Suppl 1), S161-S173. 
[187] Feng LR, \& Maguire-Zeiss KA (2010) Gene therapy in Parkinson's disease: Rationale and current status. CNS Drugs, 24, 177-192.

[188] Marks WJ Jr, Bartus RT, Siffert J, Davis CS, Lozano A, Boulis N, Vitek J, Stacy M, Turner D, Verhagen L, Bakay R, Watts R, Guthrie B, Jankovic J, Simpson R, Tagliati M, Alterman R, Stern M, Baltuch G, Starr PA, Larson PS, Ostrem JL, Nutt J, Kieburtz K, Kordower JH, \& Olanow CW (2010) Gene delivery of AAV2-neurturin for Parkinson's disease: A double-blind, randomised, controlled trial. Lancet Neurol, 9, 1164-1172.

[189] Lewitt PA, Rezai AR, Leehey MA, Ojemann SG, Flaherty AW, Eskandar EN, Kostyk SK, Thomas K, Sarkar A, Siddiqui MS, Tatter SB, Schwalb JM, Poston KL, Henderson JM, Kurlan RM, Richard IH, Van Meter L, Sapan CV, During MJ, Kaplitt MG, \& Feigin A (2011) AAV2-GAD gene therapy for advanced Parkinson's disease: A double-blind, sham-surgery controlled, randomised trial. Lancet Neurol, 10, 309-319.

[190] Mandel RJ, Burger C, \& Snyder RO (2008) Viral vectors for in vivo gene transfer in Parkinson's disease: Properties and clinical grade production. Exp Neurol, 209, 58-71.

[191] Dong Z, Wolfer DP, Lipp HP, \& Bueler H (2005) Hsp70 gene transfer by adeno-associated virus inhibits MPTP-induced nigrostriatal degeneration in the mouse model of Parkinson disease. Mol Ther, 11, 80-88.

[192] Zuo J, Baler R, Dahl G, \&Voellmy R (1994) Activation of the DNA-binding ability of human heat shock transcription factor 1 may involve the transition from an intramolecular to an intermolecular triple-stranded coiled-coil structure. $\mathrm{Mol}$ Cell Biol, 14, 7557-7568.

[193] Jung AE, Fitzsimons HL, Bland RJ, During MJ, \& Young D (2008) HSP70 and constitutively active HSF1 mediate protection against CDCrel-1-mediated toxicity. Mol Ther, 16, 1048-1055.

[194] Lo Bianco C, Shorter. J, Regulier E, Lashuel H, Iwatsubo T, Lindquist S, \& Aebischer P (2008) Hsp104 antagonizes alpha-synuclein aggregation and reduces dopaminergic degeneration in a rat model of Parkinson disease. $J$ Clin Invest, 118, 3087-3097.

[195] Dietz GP, \& Bahr M (2004) Delivery of bioactive molecules into the cell: The Trojan horse approach. Mol Cell Neurosci, 27, 85-131.

[196] Dietz GP (2010) Cell-penetrating peptide technology to deliver chaperones and associated factors in diseases and basic research. Curr Pharm Biotechnol, 11, 167-174.

[197] Lai Y, Du L, Dunsmore KE, Jenkins LW, Wong HR, \& Clark RS (2005) Selectively increasing inducible heat shock protein 70 via TAT-protein transduction protects neurons from nitrosative stress and excitotoxicity. J Neurochem, 94, 360366.

[198] Nagel F, Falkenburger BH, Tonges L, Kowsky S, Poppelmeyer C, Schulz JB, Bahr M, \& Dietz GP (2008) Tat-Hsp70 protects dopaminergic neurons in midbrain cultures and in the substantia nigra in models of Parkinson's disease. J Neurochem, 105, 853-864.

[199] Hou Y, \& Zou J (2009) Delivery of HSF1(+) protein using HIV-1 TAT protein transduction domain. Mol Biol Rep, $\mathbf{3 6}$ 2271-2277.

[200] Kim SA, Chang S, Yoon JH, \& Ahn SG (2008) TATHsp40 inhibits oxidative stress-mediated cytotoxicity via the inhibition of Hsp70 ubiquitination. FEBS Lett, 582, 734 740 .

[201] Shoulson I (1998) DATATOP: A decade of neuroprotective inquiry. Parkinson Study Group. Deprenyl and tocopherol antioxidative therapy of Parkinsonism. Ann Neurol, 44, S160-S166.

[202] Cannon JR, \& Greenamyre JT (2010) Neurotoxic in vivo models of Parkinson's disease recent advances. Prog Brain Res 184, 17-33.

[203] Magen I, \& Chesselet MF (2010) Genetic mouse models of Parkinson's disease the state of the art. Prog Brain Res, 184, 53-87.

[204] Dawson TM, Ko HS, \& Dawson VL (2010) Genetic animal models of Parkinson's disease. Neuron, 66, 646-661.

[205] Ulusoy A, Decressac M, Kirik D, \& Bjorklund A (2010) Viral vector-mediated overexpression of alpha-synuclein as a progressive model of Parkinson's disease. Prog Brain Res, 184, 89-111.

[206] Manning-Bog AB, \& Langston JW (2007) Model fusion, the next phase in developing animal models for Parkinson's disease. Neurotox Res, 11, 219-240.

[207] Lee BH, Lee MJ, Park S, Oh DC, Elsasser S, Chen PC, Gartner C, Dimova N, Hanna J, Gygi SP, Wilson SM, King RW, \& Finley D (2010) Enhancement of proteasome activity by a small-molecule inhibitor of USP14. Nature, 467, 179-184.

[208] Bove J, Martinez-Vicente M, \& Vila M (2011) Fighting neurodegeneration with rapamycin: Mechanistic insights. Nat Rev Neurosci, 12, 437-452.

[209] Fleming A, Noda T, Yoshimori T, \& Rubinsztein DC (2011) Chemical modulators of autophagy as biological probes and potential therapeutics. Nat Chem Biol, 7, 9-17.

[210] Herbst M, \& Wanker EE (2007) Small molecule inducers of heat-shock response reduce polyQ-mediated huntingtin aggregation. A possible therapeutic strategy. Neurodegener Dis, 4, 254-260.

[211] Rusmini P, Simonini F, Crippa V, Bolzoni E, Onesto E, Cagnin M, Sau D, Ferri N, \& Poletti A (2011) 17-AAG increases autophagic removal of mutant androgen receptor in spinal and bulbar muscular atrophy. Neurobiol Dis, 41, 83-95.

[212] Tokui K, Adachi H, Waza M, Katsuno M, Minamiyama M, Doi H, Tanaka K, Hamazaki. J, Murata S, Tanaka F, \& Sobue G (2009) 17-DMAG ameliorates polyglutamine-mediated motor neuron degeneration through well-preserved proteasome function in an SBMA model mouse. Hum Mol Genet, 18, 898-910.

[213] Paris D, Ganey NJ, Laporte V, Patel NS, BeaulieuAbdelahad D, Bachmeier C, March A, Ait-Ghezala G, \& Mullan MJ (2010) Reduction of beta-amyloid pathology by celastrol in a transgenic mouse model of Alzheimer's disease. J Neuroinflammation, 7, 17.

[214] Qing H, He G, Ly PT, Fox CJ, Staufenbiel M, Cai F, Zhang Z, Wei S, Sun X, Chen CH, Zhou W, Wang K, \& Song W (2008) Valproic acid inhibits Abeta production, neuritic plaque formation, and behavioral deficits in Alzheimer's disease mouse models. J Exp Med, 205, 2781-2789.

[215] Crochemore C, Virgili M, Bonamassa B, Canistro D, PenaAltamira E, Paolini M, \& Contestabile A (2009) Long-term dietary administration of valproic acid does not affect, while retinoic acid decreases, the lifespan of G93A mice, a model for amyotrophic lateral sclerosis. Muscle Nerve, 39, 548552.

[216] Zadori D, Geisz A, Vamos E, Vecsei L, \& Klivenyi P (2009) Valproate ameliorates the survival and the motor performance in a transgenic mouse model of Huntington's disease. Pharmacol Biochem Behav, 94, 148-153.

[217] Rodriguez-Navarro JA, Rodriguez L, Casarejos MJ, Solano RM, Gomez A, Perucho. J, Cuervo AM, Garcia de Yebenes J, \& Mena MA (2010) Trehalose ameliorates 
dopaminergic and tau pathology in parkin deleted/tau overexpressing mice through autophagy activation. Neurobiol Dis, 39, 423-438.

[218] Liu R, Barkhordarian H, Emadi S, Park CB, \& Sierks MR (2005) Trehalose differentially inhibits aggregation and neurotoxicity of beta-amyloid 40 and 42. Neurobiol Dis, 20, 74-81

[219] Gomes C, Escrevente C, \& Costa J (2010) Mutant superoxide dismutase 1 overexpression in NSC-34 cells: Effect of trehalose on aggregation, TDP-43 localization and levels of co-expressed glycoproteins. Neurosci Lett, 475, 145-149.

[220] Yang CR, \& Yu RK (2009) Intracerebral transplantation of neural stem cells combined with trehalose ingestion alleviates pathology in a mouse model of Huntington's disease. J Neurosci Res, 87, 26-33. 